\title{
Common Ground Management: Modal particles, Illocutionary Negation and VERUM ${ }^{1}$
}

\author{
Sophie Repp (Humboldt-Universität zu Berlin)
}

\begin{abstract}
to appear in: Daniel Gutzmann \& Hans-Martin Gärtner (Hrsg.), Expressives and beyond. Explorations of Conventional Non-Truth-Conditional Meaning. Oxford: Oxford University Press.
\end{abstract}

\begin{abstract}
This paper argues that modal particles, illocutionary negation as expressed by the operator FALSUM, and the operator VERUM are common-ground managing operators, which indicate the status of a proposition relative to the common ground (newness, expectedness, speaker commitment etc.). Common-ground managing operators can influence the truthconditional meaning of a proposition. This is shown in detail for the scopal interaction of negation and epistemic modal verbs in German. The observed effects are argued to be due to (i) the negative marker denoting either propositional negation or the operator FALSUM, and (ii) common-ground managing operators determining to a large degree the discourse appropriateness of the utterance they occur in.
\end{abstract}

\section{$1 \quad$ Introduction}

The goals of this paper are twofold. The first goal is to argue that there are operators with a common ground ( $=\mathrm{CG}$ ) managing function that can influence the truth-conditional meaning of a sentence even though their meaning usually is taken not be truth-conditional. These CGmanaging operators indicate the status of a proposition relative to the CG: (i) they indicate whether the proposition is part of the CG, or whether it is new; (ii) they indicate the interlocutors' current stance towards the proposition: whether the proposition is e.g. unexpected or obvious; and (iii) they indicate how the CG should develop: whether, and with what degree of commitment on the side of the speaker, the proposition should become part of the $\mathrm{CG}$, or be removed from it.

Illocutionary operators like ASSERT take propositions as arguments that have been assigned a CG status. This means that utterances as semantic-pragmatic units are structured as follows:

[illocutionary operator [CG-managing operator [proposition]]]

\footnotetext{
${ }^{1}$ This work was supported by the German Research Foundation DFG as part of the Collaborative Research Centre (SFB) 632 'Information Structure' within project A2 at the Humboldt-Universität zu Berlin. Very special thanks go to Andreas Haida for numerous discussions and very helpful comments. I also thank Markus Egg, Patrick Grosz and Noor van Leusen for comments on, and discussion of, earlier versions of this paper, and Horst Lohnstein and Hildegard Stommel for making available to me their VERUM focus database. I also thank the audience at the DGfS workshop Expressives and other kinds of non-truthconditional meaning at the 31st Annual Meeting of the German Society of Linguistics (DGfS).
} 
I propose that modal particles, as well as conversational epistemic operators - like the VERUM operator (Romero \& Han 2004) and illocutionary negation expressed as the operator FALSUM (Repp 2006, 2009) -, are CG-managing operators. If there is no overt CG-managing operator a default is assigned. The default is that the proposition is suggested to be added to the CG, i.e. that the proposition is new, that the speaker takes it to be true, and that the addressee's position towards it can be the subject of the next utterance.

The second goal of this paper is an empirical one: to make sense of an - at first sight very puzzling set of data involving modal verbs and negation in German. The scopal interaction of modal verbs and negation has received some attention in recent years (e.g. Ehrich 2001; Zeijlstra 2007; Penka 2010) but there are still many questions open. For instance, as we go along, it will become clear that prosody and the presence or absence of the particle auch ('also') are very important in this interaction. Yet the precise reasons for this are unexplored. I will not offer an account for the role of these two factors in this paper. I will only work with descriptive generalizations of the empirical patterns. The focus of this paper is a set of data that - as far as I am aware - have not been discussed yet at all. I am interested here in the scope relations between the negation and a modal verb in negative modalized sentences that also contain a modal particle. I will show that these data are very well suited to sharpen our understanding of the working of CG-managing operators: of illocutionary negation (= FALSUM), modal particles and VERUM. I will argue that the presence of CGmanaging operators, which bridge truth-conditional meaning and illocutionary meaning, can produce compatibility or incompatibility of a proposition with the $\mathrm{CG}$, depending on what the $\mathrm{CG}$ is and on which CG-managing operators are combined in an utterance. This then results in the availability or unavailability of certain scope relations between the negation and the modal verb.

The paper is structured as follows. In the remainder of this section I present the basic set of data, where I focus on sentences with an epistemic modal verb, negation and the modal particle doch. I do not consider root modal verbs for reasons of space, and to keep possible confounding factors to an absolute minimum. ${ }^{2}$ In section $1.1 \mathrm{I}$ discuss the notion of CG and look at the meaning and function of the FALSUM operator and the particles doch and ja. On the basis of these considerations, section 1.2 then explains why the data I present in the introduction pattern the way they do. Section 1.3 extends the empirical base to modal particles not presented in the original data set and explains the observed effects. Section 1.4 looks at VERUM and compares it to FALSUM. Section 1.5 concludes.

[space]

The German modal verb können ('can') typically scopes under negation (e.g. Öhlschläger 1989; Ehrich 2001), see (1) with können in an epistemic reading.

(2) Paul kann nicht ins Schwimmbad gegangen sein.
Paul can not to.the pool gone been
'Paul can't have gone to the pool.'

The scope relations can but need not change if the negative marker nicht ('not') receives prosodic prominence ${ }^{3}$. With an accent on nicht (2) can be understood as a rejection of a previous utterance, i.e. a denial, still with wide scope of the negation:

\footnotetext{
${ }^{2}$ For the interaction of illocutionary negation with root modals in gapping sentences see Repp (2009, chapter 4).

${ }^{3}$ To elicit a 'neutral' prosody of (2), i.e. one that expresses wide focus, a question asking for an epistemic judgement such as What do you think? seems most appropriate (in contrast to
} 
(3) A: Paul kann ins Schwimmbad gegangen sein.
B: Paul kann NICHT ins Schwimmbad
Paul can not to.the pool
A: 'Paul can have gone to the pool.'
gegangen sein.
gone been
$n e g>\bmod$
B: 'Paul canNOT have gone to the pool.'

An accent on the negative marker can also elicit a narrow scope reading of the negation, which typically occurs with additional markers such as auch ('also') (e.g. Ehrich 2001; Penka $\&$ von Stechow 2001), see (4). As a matter of fact, for a narrow scope reading to arise in sentences with epistemic können ('can') in German, the accent on the negative marker is required. ${ }^{4}$

(4) A: Paul kann ins Schwimmbad gegangen sein.

B: Paul kann auch NICHT ins Schwimmbad gegangen sein. mod $>$ neg Paul can also not to.the pool gone been

A: 'Paul can have gone to the pool.'

B: 'It is (also) possible that Paul has NOT gone to the pool.'

The last option to interpret (2) with an accent on the negative marker is as an answer to a yesno question such as Can Paul have gone to the pool?, which also results in wide scope of the negation.

The addition of the modal particle $d o c h$, whose meaning roughly can be paraphrased as 'why are you not considering $p$, you should know that $p$ ' makes the discourses in (3) and (4) (i.e. with or without auch) infelicitous, see (5). The denial reading of (3B) is not available, and the narrow scope reading of (4B) (which is more easily attainable with auch) is incoherent:

(5) A: Paul kann ins Schwimmbad gegangen sein.

B: \#Paul kann doch (auch) NICHT ins Schwimmbad gegangen sein. Paul can PART (also) not to.the pool gone been

A: 'Paul can have gone to the pool.'

B: 'It is (also) possible that Paul has NOT gone to the pool, why are you not considering this, you should know.'

*neg $>\bmod , \# \bmod >n e g$

(6B) illustrates that the disappearance of the wide scope reading is due to the combination of doch with accented nicht. Accenting another element such as Schwimmbad ('pool') produces a felicitous wide scope reading of the negation. The accent on Schwimmbad here may indicate

something like What's up? or What happened?). Thus, it seems that the meaning of such a question must relate to the epistemic status of the proposition.

${ }^{4}$ As I mentioned above, I will not explore the reasons for this in this paper. Note, however, that in the presence of the focus-sensitive particle auch ('also') the accent on the negation plausibly is interpreted as a focus accent, where the alternative to the negative polarity is the positive polarity. The negation in this case is c-commanded by the focus particle. In a minimal variant where the negation directly precedes auch and thus c-commands it, see (i), the narrow scope reading is not available.

(i) Paul kann NICHT auch ins Schwimmbad gegangen sein. $\quad n e g>\bmod ,{ }^{*} \bmod >n e g$ 
narrow focus on the DP or focus on the $\mathrm{VP} / \mathrm{vP} / \mathrm{CP}$, the latter by focus projection (Selkirk 1984), as ins Schwimmbad ('to the pool') is the complement of the verbal head. ${ }^{5}$

(6) A: Paul kann ins Schwimmbad gegangen sein.

B: Paul kann doch nicht ins SCHWIMMBAD gegangen sein.

A: 'Paul can have gone to the pool.'

B: 'Paul CAN'T have gone to the pool, why are you not considering this, you should know.'

$$
{ }^{o K} \text { neg }>\bmod , *_{m o d}>\text { neg }
$$

Furthermore, if the sentence in (5B), i.e. the sentence that contains the modal particle doch and accented negation, occurs in a context different from (5A) narrow scope becomes coherent (again most easily attainable with added auch ('also')). This is illustrated in (7B). Here the context contains the necessity modal müssen ('must'). Note, however, that as in (5B), wide scope is unavailable with this intonation.

(7) A: Paul muss ins Schwimmbad gegangen sein.

Paul must to.the pool gone been

B: Paul kann doch (auch) NICHT ins Schwimmbad gegangen sein.

Paul can PART (also) not to.the pool gone been

A: 'Paul must have gone to the pool.'

B: 'It is also possible that Paul has NOT gone to the pool, why are you not considering this, you should know.'

$*_{n e g}>\bmod ,{ }^{o k} \bmod >n e g$

This is the basic set of data that I will discuss in this paper. It will be extended with further examples as we go along. I will argue that the observed interaction of the modal particle doch and the negation in these data is due to the following. (i) The negative marker in the wide scope readings in (most of) the above examples denotes the CG-managing operator FALSUM, which basically says that the proposition it scopes over should not be in the CG. (ii) The modal particle doch denotes a CG-managing operator that instructs the hearer to retrieve this proposition from the CG. (iii) Since FALSUM and doch give conflicting instructions with respect to CG management they cannot occur in the same utterance. As a consequence, the relevant examples do not have a wide scope, i.e. denial, reading. In the case of the incoherent narrow scope reading, the negation is ordinary propositional negation. Here, we shall see that the modal particle gives instructions with respect to CG management that are incompatible with the current discourse status: it instructs the hearer to retrieve a proposition that is already currently being considered. To set the scene for the analysis of the data, the next section looks at the notion of CG, and at the negation and modal particles as CG-managing operators.

\subsection{The common ground and common-ground managing operators}

\subsubsection{The notion of common ground}

The original notion of the CG (Stalnaker 1974; Karttunen 1974; Lewis 1979) considers CG as the set of propositions which the participants in the conversation mutually agree to treat as true for the purposes of the exchange. Let us call $\mathrm{CG}$ under this definition $\mathrm{CG}_{\mathrm{t}}, t$ being a

\footnotetext{
${ }^{5}$ The English paraphrase has the accent on the auxiliary, which expresses best the surprise/indignation that the German example conveys.
} 
mnemonic for true. $\mathrm{CG}_{\mathrm{t}}$ has been a useful notion for the distinction between presuppositions vs. assertions as input requirements on $\mathrm{CG}_{t}$ vs. update effects on $\mathrm{CG}_{\mathrm{t}} \cdot \mathrm{CG}_{\mathrm{t}}$ comprises the propositions that are pragmatically presupposed.

In recent work on epistemic modals a distinction has been drawn between propositions that are taken to be true in an utterance situation, and those that the participants are aware of. Portner (2007), for instance, distinguishes between the $C G$ and the common propositional space (CPS). The former is $\mathrm{CG}_{\mathrm{t}}$, the latter is the set of propositions of which the participants in the conversation are mutually aware. $\mathrm{CG}_{\mathrm{t}}$ is thus a subset of CPS. Similarly, von Fintel \& Gillies (to appear) suggest that propositions can be 'put into play' without getting asserted, i.e. they are part of what would correspond to Portner's (2007) CPS minus $\mathrm{CG}_{t}$. Recall, however, from the introduction that even 'ordinary' assertions cannot be assumed to add propositions to $\mathrm{CG}_{\mathrm{t}}$ directly. Assertions are up for agreement or disagreement by the addressee. In belief revision systems like Wassermann (2000) this is modelled as a distinction between provisional and actual beliefs. An interlocutor can entertain a provisional belief without being committed to it (yet). ${ }^{6}$

So, according to these works an extended notion of the $\mathrm{CG}$, which is more inclusive than $\mathrm{CG}_{t}$, seems to be necessary. I suggest that the $\mathrm{CG}$ status of a proposition, as indicated by CG-managing operators, can also be part of the CG, e.g. if the interlocutors are not really committed to a proposition that proposition will be in the $\mathrm{CG}$, and its status will be that of meeting low commitment by the interlocutors. I further assume that the $\mathrm{CG}$ does not include the proposition of the immediately preceding utterance. This is a consequence of the assumption that the default CG status of that proposition is that it is suggested to be added to the $\mathrm{CG}$, that the speaker takes it to be true, and that the hearer's position towards it can be the subject of the next utterance. Therefore it is not added 'directly' to CG. This addition happens only after the addressee has accepted the proposition. This acceptance may be signalled overtly if the addressee expresses his or her agreement. If he or she does not but does not express his or her disagreement either the proposition will become part of the CG.

The term CG management was introduced by Krifka (2008) to distinguish inter alia the different kinds of contributions different kinds of speech acts make to the CG. Questions, for instance, in general do not introduce propositions that the interlocutors mutually agree to treat as true. They only have a CG-managing function and do not alter $\mathrm{CG}_{\mathrm{t}}$ directly: they signal to the interlocutor(s) how the CG should develop, and what the communicative goals of the interlocutors are. In a successful discourse, posing a question will influence the development of $\mathrm{CG}_{\mathrm{t}}$ since a cooperative interlocutor will react to a question and thereby change $\mathrm{CG}_{\mathrm{t}}$ in a way that is specified by the question. The CG-managing operators I am interested in are not speech act operators like Q or ASSERT. They scope under such speech act operators, and indicate the $\mathrm{CG}$ status of a proposition.

\subsubsection{Illocutionary negation as the CG-managing operator FALSUM}

\subsubsection{Denials: the classic view}

With Stenius (1967) the relation between a speech act and a proposition can be viewed as one between sentence mood (an illocutionary operator) and sentence radical (the proposition). I illustrate this for the negative sentence in (8), which, depending on the intonation, has the two readings in (8a) vs. (8b). (8a) is an assertion of a negative proposition. (8b) is a denial of a positive proposition. This reading might be viewed as containing what we might call

\footnotetext{
${ }^{6}$ Also see e.g. Lascarides \& Asher (2009) for the modelling of agreement, disputes and commitments in dialogue.
} 
illocutionary negation, meaning that the negation operates on the level of the illocution. ${ }^{7}$ The proposal that I put forward for denials in this paper deviates from the structure in (8b). This will be made precise further below.

(8) Max is not tall.

a. Assert ( $\neg$ Max is tall)

b. Denial (Max is tall)

Denials have been described as speech acts that remove (part of) previously introduced material from the $\mathrm{CG}\left(=\mathrm{CG}_{\mathrm{t}}\right)$ and perform a correction operation on contextual information (van der Sandt 1991). $\mathrm{CG}_{\mathrm{t}}$ in this view includes the directly preceding utterance. So, in (8b) the previously introduced material would be the proposition that Max is tall. Similarly, in (3) above, repeated below, the proposition that Paul can have gone to the pool is the proposition that is denied. The example illustrates that a typical characteristic of illocutionary negation in denials is that it carries stress (also see Horn 1989).

(3) A: Paul kann ins Schwimmbad gegangen sein.

B: Paul kann NICHT ins Schwimmbad gegangen sein. neg $>$ mod

A: 'Paul can have gone to the pool.'

B: 'Paul canNOT have gone to the pool.'

A denial can also react to an utterance that contains a negation. In this case the denial would be a positive sentence (van der Sandt 1991). I shall come back to this issue in section 1.4, where I discuss VERUM.

As a speech act, a denial can target all sorts of aspects of a previous utterance: the proposition, presuppositions, implicatures, or formal aspects. The negation of nonpropositional parts of an utterance has been called metalinguistic negation by Horn (1985, 1989) and others. Most theories of metalinguistic negation consider it a reflex of the negation taking scope over an entire utterance (cf. Jacobs 1982, 1991; van der Sandt 1991; Carston 1996). ${ }^{8}$ For instance, according to van der Sandt (1991) an echo operator takes the sum of all information of a previous utterance $\phi_{-1}$ (including implicatures, presuppositions) as the propositional content of the utterance $\phi_{0}$. This content can then be negated, which results in a denial reading. The information conveyed by $\phi_{-1}$ is removed from the $\mathrm{CG}_{\mathrm{t}}$ to avoid inconsistency. Note that in this account the negation is ordinary propositional negation. It is the echo operator that brings the entire content of the previous utterance under the scope of the negation. ${ }^{9}$

${ }^{7}$ Note that illocutionary negation is not the same as speech act negation (or 'denegation') in the sense of I am not performing the act of X (see e.g. Cornides 1969; Dummett 1973), which in the scheme proposed in (8) would correspond to:

(i) $\neg$ ASSERT(Max it tall)

${ }^{8}$ Geurts (1998) suggests that the negation of implicatures and form aspects is different from the negation of presuppositions.

${ }^{9}$ As indicated by the subscript, the 'removal' idea relates to $\mathrm{CG}_{\mathrm{t}}$. We would not want to assume that denials erase all memory of the interlocutors of a previous discourse move. Approaching this issue from a discourse theoretical perspective, Van Leusen $(2004,2007)$ makes a distinction between discourse description, and discourse meaning $\left(=\mathrm{CG}_{\mathrm{t}}\right)$. The discourse description is a set of statements in a logical language that describes the syntactic, semantic, as well as (some) pragmatic relations characterising the discourse processed, and is 
Van der Sandt's (1991) echo operator may be viewed as a CG managing device. It turns the entire contents of the previous utterance into a proposition over which propositional negation in the current utterance can take scope. Although this is a very attractive view of denials I think that it misses out on certain parallels that can be found between the negation in denials and the negation in other types of speech acts, viz. certain types of negative polar questions. Some negative polar questions can be argued to involve illocutionary negation, see below, but the assumption of an echo operator is much less plausible for them. Furthermore, even for denials an analysis in terms of an echo operator cannot account for the whole range of data. We shall see that the discourse conditions for denials are rather intricate when it comes to propositions with scalar expressions. They cannot be accounted for by the presence of an echo operator.

\subsubsection{Denials \& negative polar questions: the FALSUM operator}

The negation in negative polar questions can come as what has been dubbed in Ladd (1981) outer negation and inner negation. A negative polar question with outer negation doublechecks $p$, see (9a). A negative polar question with inner negation double-checks $\rightarrow p$, see (9b). In German this difference can be disambiguated by placing the particle auch ('also') below vs. above the negative marker (Repp 2006, 2009). In English the difference is reflected in the use of the positive polarity item too vs. the negative polarity item either (Romero \& Han 2004).
a. Schläft Peter nicht auch?
outer negation
sleeps Peter not also 'Isn't Peter sleeping too?'
b. Schläft Peter auch nicht? inner negation sleeps Peter also not 'Isn't Peter sleeping either?'

Romero \& Han (2004) suggest that these two 'types' of negation arise from the scopal interaction of the negation operator with VERUM, which is a conversational epistemic operator. Outer negation scopes over VERUM whereas inner negation scopes below it. Repp (2006, 2009) argues that outer negation in questions is not a result of the negation taking wide scope over VERUM but that outer negation is a conversational epistemic operator itself. This operator, FALSUM, is the operator that also occurs in denials. Repp supports this view with evidence for the parallel behaviour of outer negation and negation in denials with respect to their syntax (e.g. position of the negative marker with respect to focussed constituents, licensing of polarity-sensitive items), and with respect to their scopal behaviour in negative gapping sentences.

A preliminary definition of FALSUM is given in (10) below. ${ }^{10}$ In denials the variable $x$ corresponds to the speaker, in questions it corresponds to the addressee:

modelled in a discourse tree. Van Leusen argues that every utterance - including denials and corrections - increments the discourse in a monotonic way - it leads to further specifications of the discourse tree. This means that statements are never retracted from a discourse description. Denials and corrections are nonmonotonic updates when it comes to discourse meaning in the sense that a statement that is corrected will no longer be entailed by the discourse meaning.

${ }^{10}$ Repp (2009) makes a similar suggestion, which, however, is too weak to capture the discourse restrictions on denials. 
In all the worlds $w^{\prime}$ that conform to $x^{\prime} s$ knowledge in $w$ it holds that in all the worlds $w^{\prime \prime}$ that conform to the conversational goals of $x$ in $w^{\prime}$ (according to the Maxims of Quantity and Quality), the proposition in question is not in the $\mathrm{CG}\left(\mathrm{CG}_{\mathrm{t}}\right)$.

Repp (2006, 2009) suggests to link the meaning of FALSUM up to speech act theory by viewing epistemic speech act operators as expressing the degrees of strength of the sincerity conditions of a speech act. FALSUM expresses that there are zero ${ }^{11}$ degrees of strength for sincerely adding a proposition to the CG. This implies that $p$ should not be part of the CG, according to the speaker. This seems intuitive for denials if we consider them as assertions with zero degrees of strength of the sincerity conditions: a sincerity condition for assertions is that the speaker must believe that the proposition expressed is true. For questions this seems not so intuitive. A question is a directive and a directive expresses a desire. Intuitively it is not the case that in questions with outer negation the sincerity conditions for expressing a desire come with zero degrees of strength. However, the view that speech acts express attitudes like beliefs or desires is only one way of looking at them (cf. Harnish 2005). There is another view of speech acts, which is better compatible with the separation of illocutionary force and sincerity as suggested in the present paper and made explicit in the structure of utterances as given in (1) in the introductory section, repeated below for convenience:

\section{(1) [illocutionary operator [CG-managing operator [proposition]]]}

According to this other view speech acts change the commitments of speaker and/or hearer (Alston 2000; Krifka 2001; Searle 2001). For instance, by sincerely making an assertion a speaker commits him-/herself to the truth of the proposition expressed in the assertion. ${ }^{12} \mathrm{~A}$ question places the addressee under the commitment to answer, and lays down the form of the answer. From this point of view, the meaning contribution of FALSUM in polar questions can be described as follows. The speaker $s$ wishes to double-check $p$, so $s$ asks the addresses $a$ whether in all the worlds that conform to $a^{\prime} s$ knowledge in $w$ and fulfil all the conversational goals of $a$ in $w^{\prime}$, the proposition $p$ is not in the $\mathrm{CG}\left(\mathrm{CG}_{\mathrm{t}}\right)$. This corresponds to enquiring about the degrees of strengths of the sincerity conditions for adding $p$ to CG: the addressee is expected to determine whether or not there are zero degrees of strength for adding $p$ to CG, see (11):

${ }^{11}$ In Vanderveken (1990), who made a first formal suggestion for degrees of strength, zero degrees of strength is the neutral degree of strength. Stronger degrees of strength are represented by positive integers, weaker degrees of strength by negative integers. I am taking zero here to be the lower boundary for degrees of strength. Epistemic speech act operators with higher degrees of strength are for instance German wohl ('probably'), see section 1.3, and English surely.

${ }^{12}$ Searle 2001: 176 'In making an assertion we take responsibility for truth, sincerity and evidence. And such responsibilities, like commitments in general, have the upward direction of fit. These responsibilities are met only if the world is such that the utterance is true, the speaker is sincere, and the speaker has evidence for the assertion.' 
a. Ist Paul nicht ins Schwimmbad gegangen?

is Paul not to.the pool gone

'Didn't Paul go the pool?'

b. [Q [FALSUM [Paul went to the pool]]]

$=\{$ There are zero degrees of strength for adding Paul went to the pool to CG;

There are not zero degrees of strength for adding Paul went to the pool to $\mathrm{CG}\}$

Evidence for the proposal that questions of this kind indeed 'ask' for the degrees of strength comes from their answerhood conditions. When negative polar questions with outer negation in German are answered, and the addressee chooses for the option that $p$ should be added to the CG, the modal particle doch in its accented form (henceforth $D O C H$ ) must be used, rather than the neutral $j a$ ('yes'). ${ }^{13}$ This can be seen as an indication for the fact that the degrees of strength for sincerely adding $p$ to $C G$ were at issue. What degree of strength does $D O C H$ indicate? If used in isolation, i.e. if used as a replacement for yes, it seems that $D O C H$ indicates a high degree of strength. At first sight, this suggests that the paraphrase given in (11), that there are not zero degrees of strength for adding Paul went to the pool to CG, is too weak. (12) shows that it is not: it is perfectly possible to react to (11) with an utterance like (12):

(12) Doch, ich glaube schon. Ich bin mir aber nicht sicher.

PART I believe indeed I am me but not sure

'I believe he did but I am not sure.'

(12) signals that the speaker does not have enough evidence for sincerely adding Paul went to the pool to CG, i.e. there is a low degree of strength. This is compatible with the second paraphrase in (11), i.e. that there are non-zero degrees of strength. I suggest that DOCH expresses that there are non-zero degrees of strength. Depending on the context - depending on whether there are further mitigating comments or not - this can be a low, or a high degree of strength. For reasons of space I must leave open here the question of what the exact conditions are for one or the other.

I conclude from this discussion that FALSUM scopes under Q but over the proposition, as suggested in the general formula in (1) above. ${ }^{14}$ This means that a speech act consists not only of an illocutionary operator and a proposition, as in Stenius (1967), but in addition there are $C G$-managing operators. On this view, denials are assertions with the FALSUM operator.

We have just seen how the definition of FALSUM given in (10) can be fruitfully linked up to the degrees of strength of the sincerity conditions for speech acts. The degrees of strength are part of the $C G$ status of a proposition in the introductory section. In the previous section I suggested that such information must be part of the CG, where the notion of CG is extended to cover more than just the set of propositions held to be true by the interlocutors. With respect to the FALSUM operator in denials we may say that after a speaker has uttered a denial, the CG contains the information that the speaker is not committed to the truth of $p$ due to a lack of sincerity - and therefore wishes to remove $p$ from the CG.

We may of course ask whether there is independent evidence for the suggestion that information on the degrees of strength of sincerity or similar speech-act relevant information

\footnotetext{
${ }^{13}$ Note that accented doch has a different meaning from unaccented doch. Only the latter will be investigated in the remainder of this paper.

${ }^{14}$ See Repp (2006) for further arguments from gapping that support this kind of structure.
} 
indeed is part of the CG, or of a directly preceding utterance. I suggest that there is. Information of this kind can be called into question by an interlocutor independently of the truth of the 'bare' proposition (i.e. the proposition whose CG status has not been specified). Consider the following exchange:

(13) Context: Speaker A does not have a watch, or access to some other time-telling gadget. Speaker B has a watch, and knows that speaker A does not know the time. It is 3 o'clock. A: It is 3 o'clock.

B: That's a very good guess.

Speaker B here implies that A cannot make an assertion with totally being committed to it because A does not have access to information about the time. So B says that A is guessing, i.e. has a rather low degree of strength of sincerity for his or her assertion. This information is independent of the fact that the proposition expressed by A is true in this context. Similarly, consider the scenario in (14). It seems quite adequate for speaker B in this context to tell A that A was not sincerely making an assertion even though the proposition that A expressed is true in this context.

(14) Context: Speaker A wants to fool speaker B about the time. A looks at his or her watch, which says that it is $10 o^{\prime}$ clock without realizing that the watch is actually an hour fast. $B$ can see A's watch but knows that it is in fact 9 o'clock.

A: It is 9 o'clock.

B: You're lying - but you're telling the truth.

A final example concerns the operator VERUM. Repp $(2006,2009)$ proposes that like FALSUM, VERUM is an operator that expresses the degrees of strength of the sincerity conditions. In the case of VERUM this is the maximum degree of strength. I follow this proposal here. Example (15) illustrates that the high degree of strength expressed by VERUM can be questioned by a second speaker even though that speaker shares the opinion of the first speaker with respect to the truth of the proposition at hand:

(15) A: My friend Mary said that Peter is a zombie.

B: He IS a zombie.

C: Why are you so certain about this? I also think that he's a zombie but we should check this to make absolutely sure.

Again, this indicates that the sincerity of a speaker can be taken issue with independently of the truth of the proposition expressed.

Let us move on to the discourse conditions of FALSUM. In our discussion of previous approaches to denials in section 1.1.2.1 we heard that denials are reactions to information that has been expressed before: denials react to an immediately preceding utterance that proposes to add the proposition at issue to the set of propositions that are held to be true by both interlocutors. This condition on the discourse is not part of the meaning of FALSUM given in (10). It cannot be added innocently, though, because polar questions with outer negation seem to behave differently with respect to their discourse context. In polar questions with outer negation the speaker conveys a previous epistemic bias towards $p$ and wishes to double-check that $p$ is part of the CG. This is done by using FALSUM. The proposition $p$ in this case, however, is not part of the CG but of the private assumptions of the speaker: polar questions with outer negation are felicitous with a(n immediately) preceding context that entails $\neg p$, or one that entails neither $p$ nor $\neg p$ but not with one that entails $p$ (Büring \& Gunlogson 2000). 
So although FALSUM scopes over a positive proposition both in the case of denials and in the case of questions the contextual restrictions are different. I suggest that we capture this difference by making the context restrictions dependent on whether the variable $x$ denotes the speaker or the addressee. Clause (i) in (16) captures the discourse conditions for declaratives (i.e. denials), clause (ii) captures the conditions for questions. Clause (ii) summarizes the generalization proposed by Büring \& Gunlogson (2000). Clause (i) requires some further comments. I shall come to that presently.

$$
\llbracket \text { FALSUM } \rrbracket^{x}=\lambda p_{<\mathrm{s}, \mathrm{t}} \lambda \boldsymbol{} w . \forall w^{\prime} \in \operatorname{Epi}_{x}(w)\left[\forall w^{\prime \prime} \in \operatorname{Conv}_{x}\left(w^{\prime}\right)\left[p \notin \operatorname{CG}_{w^{\prime \prime}}\right]\right]
$$

Discourse condition for utterance $u_{n}$ with $\llbracket$ FALSUM $\rrbracket^{x}(p)$ :

(i) for $x=$ speaker: $u_{n-1}$ entails strengthened $p$ (i.e. with the meaning of $p$ including its scalar implicatures)

(ii) for $x=$ addressee: $u_{n-1}$ does not entail $p$

Clause (i) of the above definition says that in a denial, the previous utterance must entail strengthened $p$. The motivation for this comes from examples like (17) and (18). (17) suggests that FALSUM can be used felicitously if the proposition in its scope is entailed by the previous utterance: smoking a cigar entails smoking.

(17) A: Paul hat gestern Zigarre geraucht

Paul has yesterday cigar smoked.

B: Paul hat NICHT geraucht.

Paul has not smoked.

A: 'Paul smoked a cigar yesterday.'

B: 'Paul DIDn't smoke.'

In (18), eating three biscuits entails eating two biscuits. Nevertheless, applying FALSUM to the proposition that Peter ate two biscuits is incoherent in the given context:

(18) A: Peter ate three biscuits.

B: Peter DIDn't eat three biscuits.

B': \#Peter DIDn't eat two biscuits.

The crucial difference between (17) and (18), I suggest, is that (18) contains a scalar expression whereas (17) does not. Geurts (1998) observes that scalar expressions under denial receive an 'exactly' reading. So, speaker B' in (18) says that the proposition that Peter ate exactly two biscuits should not be in the CG. This is not entailed by $u_{n-1}$. Therefore, using FALSUM in this discourse produces incoherence. Note that under propositional negation scalar expressions do not receive an 'exactly' reading. Rather, the upper boundary (not more than 2) is suppressed, just as with other downward entailing operators (e.g. Chierchia 2004; Geurts 2009). The meaning of the sentence in (19) entails not (19.i) but (19.ii):

(19) Peter did not eat 2 biscuits.

(i) Either Peter ate less than two biscuits or Peter ate more than two biscuits.

(ii) Peter ate less than two biscuits.

According to the definition in (18) the 'exactly' reading in denials is part of the meaning of FALSUM: if FALSUM scopes over a proposition with a scalar expression, the meaning of this proposition is strengthened, i.e. the 'at least' reading is strengthened to the 'exactly' reading. 
This then explains the difference between the acceptability of the discourses in (17) and (18): (17B) has no scalar implicature. The strengthened meaning is identical to the nonstrengthened meaning, and this is entailed by $u_{n-1}$. The discourse is coherent. In (18) the strengthened meaning of the proposition in the scope of FALSUM is that Peter ate exactly two biscuits, which is not entailed by $u_{n-l} \cdot{ }^{15}$

\subsubsection{Modal particles as CG-managing operators}

Modal particles have been ascribed different functions on the speech act level. Most commonly they have been considered modifiers of illocution types, e.g. Thurmair (1989), Lindner (1991), Jacobs (1991), Waltereit (2001), Karagjosova (2004), Zimmermann (2004). The particular way in which an illocution type can be modified differs in these approaches. For instance, for $j a$, which means something like 'recall', Jacobs (1991) suggests that it may change the illocutionary type from a general type (e.g. assertion) to a more specific one (e.g. $j$-assertion), which has additional meaning postulates. Waltereit (2001) and Karagjosova (2004) argue that a modal particle changes the preparatory conditions of a speech act. For example, if an assertion, which comes with the preparatory condition that it is not obvious to both speaker and hearer that the hearer knows $p$ and does not need to be reminded of $p$ (Searle 1969), use of the particle $j a$ indicates that the speaker thinks that the interlocutors share the conveyed information and that in the present context it should be activated. This clashes with the above-mentioned preparatory condition, which can then be cancelled (Waltereit 2001).

More generally, Thurmair (1989) says that modal particles have the function to integrate an utterance into the current context: they are used to point to common knowledge of the interlocutors, to assumptions and expectations of speaker and hearer with respect to a previous, or with respect to the current utterance. Similarly, Karagjosova (2004) characterizes modal particles as conveying interaction-regulating instructions to the hearer by indicating the speaker's view on the cognitive status of the propositional content of past and current utterances and beliefs. These meaning contributions are contributions about what I called the $C G$ status of a proposition above: modal particles are CG-managing operators that indicate the $\mathrm{CG}$ status of a proposition.

${ }^{15}$ One might wonder what the status of presuppositions in these denial scenarios is. (i) shows that an accented negation, which I have assumed denotes FALSUM in declarative sentences, cannot occur in discourses where a presupposition is rejected. The appropriate intonation is the one where there is an accent on the finite auxiliary, i.e. an intonation contour that we find with VERUM focus (see section 1.4).

(i) A: Peter hat aufgehört $\mathrm{zu}$ rauchen.

Peter has stopped to smoke

B: \#Peter hat NICHT geraucht.

B': Peter HAT nicht geraucht.

Peter has not smoked

A: 'Peter has stopped smoking.'

$B \& B^{\prime}$ : 'Peter did not smoke before.'

I do not have the space to discuss this here but observe that examples like (i) are different from the cases of presupposition denial that are normally discussed in the literature, e.g. (ii). In (ii) the entire previous utterance is rejected and then the reason for the rejection is given: viz. that the speaker of the denial takes issue with the presupposition:

(i) A: Peter has stopped smoking.

B: Peter HASN'T stopped smoking: he never DID smoke.

See e.g. Geurts (1998) for an account of presupposition denials of the sort in (ii). 
For $j a$ and doch (recall that the latter figured prominently in the set of data presented in section 1) we can state that they are used by the speaker to instruct the hearer to retrieve from $\mathrm{CG}$ a proposition which is not currently being considered, i.e. a proposition that was not conveyed as part of the meaning of the directly preceding utterance. ${ }^{16}$ Doch comes with the additional meaning component that the current proposition is at odds with a proposition or an implicature that was suggested to be added to the CG with the previous utterance, or that was presupposed in that previous utterance. ${ }^{17,18}$ In (20) and (21) I give definitions of what I mean by retrieve, and specify the discourse restrictions for ja vs. doch in a way similar to the definition of FALSUM I proposed in the previous section. These definitions capture the suggestions in the literature that I just summarized. Note that clause (ii) of definition (20), which is part of the definition of the retrieval function (it makes sure that the proposition that is to be retrieved is not part of the immediately preceding utterance, recall that CG does not include this utterance) is subsumed by clause (ii) of definition (21). So both ja and doch have this retrieval function. Still, I shall substantially revise the definition of doch in section 1.2.1 (definition (28)) as the contrast relations that have been suggested for doch and that are captured by clause (21.ii) are not entirely adequate.

${ }^{16}$ Note that both doch and ja can actually occur discourse-initially, e.g.

(i) Du hast ja einen Zettel auf dem Rücken kleben! you bleed PART a note on the back stick 'There's a note stuck on your back!'

(ii) Maria, du warst doch schon mal auf Teneriffa. M. you were PART already once on Tenerife 'Mary, you've been to Tenerife before, haven't you?'

For $j a$ this is unproblematic since it is used to signal familiarity and the immediately preceding utterance is just restricted to not entailing, implicating or presupposing the proposition of the ja-utterance. This is trivially fulfilled in the discourse-initial case. For doch it is often assumed that it calls the hearer to consider the propositional content of the current utterance because there was evidence that s/he had not done that before (e.g. Thurmair 1989, Karagjosova 2004). A zero context is compatible with not considering that content.

Karagjosova also points out that the discourse-initial use of doch provides a common basis for further discourse by activating common knowledge: the hearer is asked to synchronize his/her beliefs with that of the speaker. So in (ii) the speaker sets the scene for a conversation that is to be taken up after the confirmation by the hearer Mary - that she indeed has been to Tenerife - say, by inquiries about Tenerife. Note that without doch, this utterance would be very impolite (although there are options to make it polite without using doch, e.g. by placing an accent on $d u$ ('you')).

${ }^{17}$ This is a simplification. For larger discourses, this condition should probably be extended to the immediately preceding discourse section and not just the previous utterance - which, however, still awaits detailed investigation. Since the discourses I am looking at contain only two utterances this simplification is harmless. Furthermore, note that 'being at odds' essentially means that from the previous discourse it can be inferred that $\neg p$ (see Egg, this volume).

${ }^{18}$ Also compare Karagjosova (2004), who discusses the fact that modal particles may react to implicatures, and Egg (this volume), who shows that utterances containing doch often are used to reject presuppositions of the previous utterance. 
(20) $\llbracket j a \rrbracket=\llbracket R E T R I E V E \rrbracket=\lambda p_{<\mathrm{s}, \uparrow .} . \mathrm{p}$

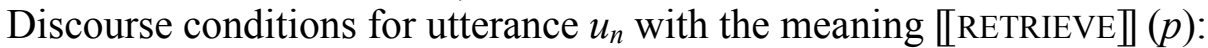

(i) CG entails or implicates $p$

(ii) $u_{n-l}$ does not entail, presuppose or implicate $p$.

(21) to be revised

$\llbracket d o c h \rrbracket=\lambda p_{<\mathrm{s}, \triangleright \mathrm{p}} \mathrm{p}$

Discourse conditions for utterance $u_{n}$ with the meaning $\llbracket d o c h \rrbracket(p)$ :

(i) CG entails or implicates $p$

(ii) $u_{n-l}$ entails, presupposes or implicates $\neg p$.

Before we move on to the combinatorial possibilities of different CG managing operators I would like to discuss briefly the assumption that nicht ('not') actually is a modal particle without negative force (see e.g. Helbig 1988, Thurmair 1989), and reject it (cf. Meibauer 1990, 1994; Rosengren 1992). Modal, non-negative nicht is said to occur in polar questions and in $w h$-exlamatives. ${ }^{19}$ For polar questions with negation we saw above that they convey that the speaker has a certain bias with respect to the expected answer. For questions with outer negation, we saw that this pragmatic effect can be accounted for in terms of the CG managing operator, FALSUM. For inner negation, we saw that the effect can be explained as one of the - meaningful - negation scoping under the VERUM operator. This kind of analysis receives strong support from the observation that negative polar questions have very similar pragmatic effects in languages that do not have modal particles, such as English (Ladd 1981; Romero \& Han 2004), or Spanish (Ibañez 1972). So postulating the existence of a nonnegative particle for German seems unwarranted. Turning to $w h$-exclamatives ${ }^{20}$ we find that, again, the occurrence of an apparently non-negative negative marker is a cross-linguistic phenomenon. It has been reported e.g. for French (van der Wouden 1994; Muller 1991), Catalan (Espinal 2000; Castroviejo Miró 2006), Spanish (Espinal 2000) and Paduan (Portner \& Zanuttini 2000). Again, this suggests that a modal particle analysis is not very appealing (cf. Meibauer 1990; Portner \& Zanuttini 2000; Roguska 2008). Without engaging in this discussion any further I conclude that nicht never is a non-negative modal particle in German. $^{21}$

${ }^{19}$ There are other contexts where nicht has been suggested to be semantically void, e.g. socalled 'expletive negation' in German before-sentences, and counterfactuals, see Schwarz \& Bhatt (2006). Krifka (2010) offers an account for before-sentences where nicht has negative force. See Yoon (2011) for a general account of 'expletive' negation that takes the negation to be negative, i.e. non-void.

${ }^{20}$ Here is an example.

(i) Wen HAT die nicht alles eingeladen! whom has she.DEM not all invited! 'All the people she invited!'

${ }^{21}$ We can observe these two scopal options in exclamatives too. Compare the following minimal variant of (i) in footnote 20 above:

(i) Wen die alles NICHT eingeladen hat! whom she.DEM all not invited! has 'All the people she DIDN'T invite!'

Here, the negative marker occurs below the quantifier and must be accented to be felicitous, which is due to the utterance being contrastive in the context of an explanation where 


\subsubsection{Combining modal particles}

Modal particles can be combined. Thurmair (1989) looks at potential combinations of a great number of German modal particles and describes two general types of restrictions. The first type are restrictions individual particles have with respect to the sentence type they can occur in: in the great majority of cases a combination of particles is impossible if the individual particles cannot occur in the same sentence type. ${ }^{22}$ For instance the particle etwa (which expresses unexpectedness or undesirability) can only occur in polar questions, whereas halt (which signals that the current proposition is a plausible explanation for the previous proposition), can only occur in declaratives or imperatives. These two particles cannot be combined. The second type of restrictions are pragmatic restrictions. For instance, particles which signal that the current utterance is meant as an explanation for the previous utterance, such as eben ('obviously', 'immutably'), halt ('obviously') and einfach ('just') cannot be combined with particles like $e$ and sowieso (both roughly meaning 'anyway'), which restrict the relevance of the previous utterance to the point that they signal that it is irrelevant. Thus, these particles signal contradicting communicative functions of the current utterance.

Let us turn to the retrieval particles doch and ja. A paper by Lindner (1991) on modal particles carries the title given in (22), which combines ja ('retrieve') and doch ('retrieve \& contrast').

(22) Wir sind ja doch alte Bekannte.

we are PART PART old acquaintances

Roughly: 'We are old acquaintances, you must agree, mustn't you, because you know it as well as I do.'

The fact that $j a$ and doch can be combined follows from the definitions I gave in (20) and (21). The meaning contribution of the two particles is the same, and the discourse conditions ja imposes on its context are a subset of those that doch imposes on its context. The two particles may happily combine. ${ }^{23}$ With this much in hand let us examine the modalized negative sentences from the introduction.

\subsection{Explaining the data: $d o c h, j a$ and negation}

I will start my discussion with example (5) from the introduction, repeated below, where speaker B's utterances contains an accented negative marker. Wide scope of the negation over the modal is not available in this case. Narrow scope is incoherent.

someone is surprised at the number of people 'she' invited. The negation operates on the propositional level.

${ }^{22}$ As one exception Thurmair mentions denn, which cannot occur in declaratives on its own but in combination with doch and $j a$, it can.

${ }^{23}$ There is an ordering restriction: $j a$ has to occur before doch. I have nothing to say about this here. 
(5) A: Paul kann ins Schwimmbad gegangen sein.

B: \#Paul kann doch (auch) NICHT ins Schwimmbad gegangen sein. Paul can PART (also) not to.the pool gone been

A: 'Paul can have gone to the pool.'

B: 'It is (also) possible that Paul has NOT gone to the pool, why are you not considering this, you should know.'

$*_{n e g}>\bmod , \# \bmod >$ neg

In the following I will first explore why narrow scope is incoherent in this example (subsection 1.2.1). This will lead to a redefinition of the meaning of $d o c h$, for which I formulated a preliminary version in subsection 1.1.3. Afterwards I will turn to the unavailability of the wide scope reading (subsection 1.2.2). I will close this section with an investigation of example (6) from the introduction, where the negation in speaker B's utterance is not accented (subsection 1.2.3).

\subsubsection{Doch, $j a$ and an accented negative marker: narrow scope}

The reason for the incoherence of the narrow scope reading in example (5), I suggest, is that it is implicated by (5A), see (23):

(23) $\exists w^{\prime} \in \operatorname{Epi}_{\mathrm{x}}(w) \wedge$ Paul went to the pool in $w^{\prime}$

implicates $\quad \neg \forall w^{\prime} \in \operatorname{Epi}_{\mathrm{x}}(w) \wedge$ Paul went to the pool in $w^{\prime}$

$\Leftrightarrow \exists w^{\prime} \in \operatorname{Epi}_{\mathrm{x}}(w) \wedge$ Paul didn't go to the pool in $w^{\prime}$

Clause (ii) of definition (21) says that the previous utterance must entail, presuppose or implicate $\neg p$, which in the case of (5) means that (5A) must entail, presuppose or implicate that it is not possible that Paul did not go to the pool. However, as we just saw (5A) implicates the opposite. A discourse condition for using doch is not met. Therefore the use of doch is not licensed.

We might ask, of course, whether the incoherence of (5) indeed is due to the retrieval aspect, or whether it maybe is due to the apparently missing contrast. We can find out by comparing (5) to an example where there is contrast but no retrieval, and to an example where there is retrieval but no contrast. The former would be a comparison with an utterance where doch is replaced by aber ('but'), which I will show to have the same contrast indicating function as doch. The latter would be a comparison with an utterance where doch is replaced by $j a$, which we already know to signal retrieval but no contrast. I will start with aber.

(24) is a variant of (5B) where the conjunction aber ('but') replaces doch. ${ }^{24}(24)$ is a felicitous discourse.

(24) A: Paul kann ins Schwimmbad gegangen sein.

B. Paul kann aber auch NICHT ins Schwimmbad gegangen sein. Paul can but also NOT to.the pool gone been

A: 'Paul can have gone to the pool.'

B. 'But it is also possible that Paul did NOT go to the pool.'

$\bmod >n e g$

To make the comparison between doch and aber valid let us investigate the contrast relations expressed by these two elements in detail. The contrast expressed by aber is often thought to

\footnotetext{
${ }^{24}$ The accent on the negative marker is required here.
} 
express that a coordination or utterance sequence $q$ but $p$ corresponds to: $q$ and therefore $\neg p$, but actually $p$ (cf. Lakoff 1971). The 'therefore' part refers to inference patterns that are based on world knowledge or linguistic context. This is quite similar to what Egg (this volume) suggests for $d o c h$, except that the direction of inference is reversed ( $p$ and therefore $\neg q$ ) and $p$ is not assumed to be in the CG already and therefore is not retrieved from the CG. ${ }^{25}$ This characterization of the meaning contribution of aber, which was suggested by Lakoff (1971) and much subsequent literature, is actually a special case of a more general formula where the inference relation between $q$ and $p$ in an utterance (sequence) $q$ but $p$ is not quite so direct. According to e.g. Anscombre \& Ducrot (1973), Lang (1991), and Merin (1996), $q$ is assumed to support a certain proposition in the background (typically an inference) whereas $p$ is assumed to go against this proposition. This is captured in the following definition:

(25) $\llbracket$ aber $\rrbracket=\lambda p_{<\mathrm{s}, \mathrm{t} . \mathrm{p}}$

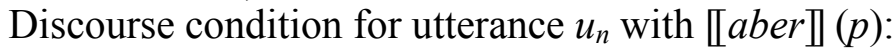

(i) $u_{n-1}$ defeasibly entails $r$

(ii) $p$ defeasibly entails $\neg r$.

Let us apply this definition to the dialogues in (26). ${ }^{26}$

(26) i. A: Barbara leitet die Sitzung. Barbara chairs the meeting

B: Aber PETER ist Abteilungschef. but Peter is head.of.department

A: 'Barbara is chairing the meeting.'

B: 'But [Peter $\left.{ }_{F o C}\right]$ is head of department.'

ii. A: Peter leitet die Sitzung nicht. Peter chairs the meeting not

B: Aber Peter ist AbTeIlungschef. but Peter is head.of.department

A: 'Peter is not chairing the meeting.'

B: 'But Peter is [head of department Foc].'

First consider speaker B's utterance in (26.i). The subject Peter is focus-marked here (small capitals mark a falling pitch accent), which indicates that all contextually available alternatives to Peter are not head of department. A contextually available alternative is Barbara. Why would speaker B want to focus-mark Peter and express the resulting meaning? After all, the A-utterance says that Barbara chairs the meeting, and not that she is head of department, so there does not seem to be a proposition of the form $x$ is head of the department where $\mathrm{x} \neq$ Peter in the immediate context as suggested by the subject focus. Now, note that the exchange in (26.i) would be somewhat incoherent without the conjunction aber. Further, recall that aber has the effect that the utterances it links are related by inference to a proposition $r$, i.e. a third proposition in the background. Let us assume that in a situation where (26.i) can be uttered felicitously there is a department rule like Meetings are chaired by

\footnotetext{
${ }^{25}$ Egg's (this volume) definition of doch: $p$ ist the doch-proposition, $q$ is an antecedent proposition.

$\llbracket \operatorname{doch} \rrbracket(\mathrm{p})(\mathrm{q})$ iff both $p$ and $p>\neg q$ are part of the common ground

${ }^{26}$ I owe these examples to Andreas Haida.
} 
the head of department. From this and the utterance of A it can be inferred that Barbara is head of department (= proposition $r$ ). B takes issue with $r$, which is why s/he uses aber. Peter is focus-marked as a direct consequence of the proposition $r$ being in the immediate context: Peter in (26.ii.B) is a corrective focus with Barbara as the corrected alternative.

(26.ii) is similar. Let us assume the same department rule. From A's utterance it can be inferred that Peter is not head of department - let us pretend we are in a guessing puzzle of the who-is-who kind where unforeseeable obstacles like Peter's being ill are not an option. If Peter is not head of department he is a simple employee (= proposition $r$ ). This is the proposition speaker B takes issue with because it is incompatible with Peter being head of department. Again, the focus marking is a consequence of the proposition $r$-that Peter is $a$ simple employee - being in the immediate context.

Let us turn next to a minimal variant of the above data set, where instead of aber, doch occurs, viz. (27). (27) shows that the data pattern exactly the same.

(27) i. A: Barbara leitet die Sitzung.

Barbara chairs the meeting

B: PETER ist doch Abteilungschef.

Peter is PART head.of.department

A: 'Barbara is chairing the meeting.'

$B$ : '[Peter Foc] is head of department. You should know, why are you not considering this?'

ii. A: Peter leitet die Sitzung nicht.

Peter chairs the meeting not

B: Peter ist doch AbTEIlungschef.

Peter is PART head.of.department

A: 'Peter is not chairing the meeting.'

B: 'Peter is [head of department ${ }_{\text {Foc }}$ ].You should know, why are you not considering this?'

I would like to argue that the reasoning for the doch-cases in (27) also is exactly the same as for the aber-cases in (26). I illustrate this for the example with subject focus. So assuming the same department rule as above it can be inferred from speaker A's utterance that Peter is not head of department: if Barbara is chairing the meeting she must be head of department. B says that it is Peter that is head of department. The focus marking on the subject indicates that a proposition of the form $x$ is head of the department is in the immediate context where $x \neq$ Peter. This is compatible with B's utterance. We find that the contrast relations are exactly the same in the doch-and in the aber-examples. The difference between the two cases is that in the former there is the component of retrieval: by using doch speaker B indicates that the proposition that Peter is head of department is already in CG. The aber-utterances do not have this meaning component.

As a consequence of the above discussion I suggest that we amend our definition of doch in a way that captures the parallelism in contrast formation between aber and doch, viz. that there is a third proposition $r$ that is relevant for the contrast (clauses (iii) and (iv) in the definition in (28). The fact that doch also has a retrieval function is captured by the same two clauses that made up the discourse conditions for the particle ja (see definition (20i. \& ii)). 
(28) $\llbracket d o c h \rrbracket=\lambda p_{<\mathrm{s}, \mathrm{t}>\mathrm{p}}$

Discourse condition for utterance $u_{n}$ with the meaning $\llbracket d o c h \rrbracket(p)$ :

(i) CG entails or implicates $p$

(ii) $u_{n-1}$ does not entail, presuppose or implicate $p$.

(iii) $u_{n-1}$ defeasibly entails $r$

(iv) $p$ defeasibly entails $\neg r$.

With this let us turn back to example (5) for which I suggested that the narrow scope reading is not available because this reading is an implicature of the A-utterance and therefore it is impossible to retrieve it. The data in (24), the aber-case, vs. those in (5) tell us that uttering the implicature of the previous utterance is harmless in comparison to instructing the addressee to retrieve it. (5) is incoherent whereas (24) is not. What about the contrast involved in (5)? I suggest that this contrast concerns what we might call purpose-guided hypothetical reasoning. Speaker A says that Peter might have gone to the pool $(=\diamond q)$. If the issue of the conversation is to get hold of Peter a reasonable move as a reaction to Speaker A's utterance would be to try the pool to find Peter, i.e. to assume that Peter indeed has gone to the pool. We might express this with the proposition we will find Peter at the pool $(\diamond q$ defeasibly entails $r)$. This then contrasts with B's suggestion that Peter might be somewhere else $(\diamond \neg q=$ $p ; p$ defeasibly entails $\rightarrow r$ ). This is the same in (5) and (24).

Further evidence for the suggestion that it is indeed the retrieval function that is at issue in (5) comes from another minimal variant of (5), viz. (29), where doch is replaced by ja, which has a retrieval function but does not signal contrast. (29), like (5) is incoherent. ${ }^{27,} 28$

(29) A: Paul kann ins Schwimmbad gegangen sein.

B. \#Paul kann ja auch NICHT ins Schwimmbad gegangen sein.

Paul can PART also NOT to.the pool gone been

A: 'Paul can have gone to the pool.'

B: 'It is also possible that Paul DIDn't go to the pool, recall.'

$\bmod >$ neg

${ }^{27}$ An anonymous reviewer debates this judgement for the $j a$-variant but note that a legitimate reaction of speaker A would be to reject (29B) as a superfluous contribution to the conversation, which shows that it is not an appropriate move by speaker B.

${ }^{28}$ An anonymous reviewer points out that there are examples which suggest that indicating the retrieval of an implicature by the use of $j a$ is generally possible:

(i) Einige Studenten haben die Klausur bestanden. Und da ja nicht alle Studenten die

Klausur bestanden haben, muss es eine Nachklausur geben.

'A few students did not pass the exam. And since not all the students passed there will be a second exam.'

An important difference between this example and those discussed above is that it does not involve a turn of speaker. I suggest that it is a legitimate move on the side of the speaker to draw attention to the implicature of his/her own previous utterance as $\mathrm{s} /$ he cannot be sure that the addressee was attentive enough. Such an attention-directing move is inadequate for someone else's utterance because that other person would have chosen a different utterance had s/he not been aware of the meaning component carried by the implicature. The different behaviour of $j a$ in same-speaker utterance sequences can be captured by relativizing the meaning of $j a$ to speakers similarly to the case of the FALSUM operator (definition (16)). 
So instructing the addressee by the use of doch or ja to retrieve a proposition from the CG is an inadequate instruction with respect to the CG status of that proposition if it is part (e.g. as an implicature) of the current exchange $\left(u_{n-1}\right)$.

Finally observe that the narrow scope reading becomes available in the doch-sentence if there is no implicature in the left sister that is to be retrieved in the right sister. This is illustrated with the same example in a different context, viz. example (7) from the introduction, repeated below. Again the negative marker is accented here, which is required for a narrow scope reading (but did not save the same example in the context of (5)):

(7) A: Paul muss ins Schwimmbad gegangen sein.

B: Paul kann doch (auch) NICHT ins Schwimmbad gegangen sein.

A: 'Paul must have gone to the pool.'

B: 'It is also possible that Paul DIDn't go to the pool, why are you not this, you should know.'

considering

$$
{ }^{*} n e g>\bmod ,{ }^{o k} \bmod >n e g
$$

(7A) does not implicate, presuppose or entail the proposition $p=\diamond \rightarrow q$ expressed in (7B). The discourse is coherent on a narrow scope reading.

\subsubsection{Doch and an accented negative marker: wide scope}

The next question to ask with respect to example (5), which we discussed in the previous section, is why the wide scope reading is not available.

(5) A: Paul kann ins Schwimmbad gegangen sein.

B: *Paul kann doch (auch) NICHT ins Schwimmbad gegangen sein. Paul can PART (also) not to.the pool gone been

A: 'Paul can have gone to the pool.'

B: 'It is (also) possible that Paul has NOT gone to the pool, why are you not considering this, you should know.'

*neg $>\bmod , \# \bmod >n e g$

In the introductory section I suggested that the wide scope reading in this example is a denial reading, and in section 1.1 I defined denials as assertions with the FALSUM operator. For (5) this means that we have two CG-managing operators: FALSUM and doch. FALSUM signals that the proposition it scopes over that Paul can have gone to the pool should be removed from CG. doch instructs the addressee to retrieve this proposition from CG and keep it in CG. We observe that FALSUM and doch give opposing instructions with respect to CG management. They cannot occur in the same utterance. In addition to this conflict there also is the fact that doch instructs the addressee to retrieve a proposition that was just uttered beforehand. This violates one of the discourse conditions of doch. Note that all this also carries over to the particle ja, for which an example was given in the previous section, example (29B).

\subsubsection{Doch and an unaccented negative marker}

Example (6) in the introduction, repeated below for convenience, contains the modal particle doch and an unaccented negative marker, which suggests that the negative marker does not express FALSUM but propositional negation. Thus doch is the only CG-managing operator in (6). It retrieves the wide scope reading from CG. If we assume that the proposition $r$ in the background is something like we will find Paul by the pool, as I suggested earlier, we find that from (6A) it can be defeasibly inferred that $r$, whereas from (6B) on a wide scope reading it 
can be defeasibly inferred that $\neg$. This is an appropriate use of doch according to definition (28).

(6) A: Paul kann ins Schwimmbad gegangen sein.

B: Paul kann doch nicht ins SCHWIMMBAD gegangen sein.

A: 'Paul can have gone to the pool.'

B: 'Paul CAN'T have gone to the pool, as you should know.'

$$
{ }^{\text {oK }} \text { eg }>\bmod ,{ }^{*} \bmod >\text { neg }
$$

Note as an aside that (6B) with the above intonation is infelicitous without doch in this context. This is expected given that it is only the polarity that is different in the two sentences. In a discourse that is coherent with respect to information-structural requirements, we therefore expect the polarity of the second sentence, i.e. the negation, to carry an accent: the negative polarity is the focus in this sentence, which is marked prosodically in German. Curiously, the presence of doch seems to make the accent marking unnecessary. As a matter of fact, we already observed that an accent on the negation in this example actually results in infelicity (example (5)). As for the missing narrow scope reading of (6B) I suggest that it is not available because narrow scope must be indicated by an accent on the negative marker (see the introduction).

\subsection{More data: Other modal particles}

Let us look at some more modal particles to corroborate the present analysis. The examples in (30) show the available scope options for a negative marker interacting with modality in mini discourses like those above with one of the following modal particles: eben ('evidently', 'immutably'), einfach ('just'), ruhig ('no worries'), schon ('admittedly'), wohl ('presumably'). These particles all can occur in declarative sentences, the sentence type under investigation here. They do not have retrieval or rejection functions.

The behaviour of these particles in the discourses in (30) is quite diverse: one particle ruhig - cannot combine at all with an accented negative marker independent of the context. Other particles can combine with an accented negative marker but the scope options are limited, which in turn might lead to incoherence in the context of (30A). Note that in general - and as we already saw above - the narrow scope reading, if available, really only is felicitous if auch ('also') is placed before the negative marker (which for reasons of readability is not indicated below). 
(30) A: Paul kann ins Schwimmbad gegangen sein.

A: 'Paul can have gone to the pool.'

B.i: Paul kann eben NICHT ins Schwimmbad gegangen sein.

'No, Paul obviously canNOT have gone to the pool'

neg $>$ mod,

\#mod $>$ neg

B.ii \#Paul kann einfach NICHT ins Schwimmbad gegangen sein.

$*_{n e g}>\bmod$,

'Paul simply canNOT have gone to the pool.'

\#mod $>$ neg

B.iii *Paul kann ruhig NICHT ins Schwimmbad gegangen sein. no translation

B.iv \#Paul kann schon NICHT ins Schwimmbad gegangen sein. 'Paul indeed may not have gone to the pool, but...'.

*neg>mod,

*mod $>$ neg

*neg $>$ mod, $\#$ mod $>$ neg

B.v \#Paul kann wohl NICHT ins Schwimmbad gegangen sein.

*neg $>$ mod, 'I consider it likely that it is possible that Paul has not gone to \#/?mod>neg the pool.'

Let us start with (30B.iii), with ruhig, which is ungrammatical under any reading. The particle ruhig signals reassurance, and is known to occur only ${ }^{29}$ together with modals or imperatives (see e.g. Thurmair 1989; Grosz 2009; Schwager 2010). Importantly, ruhig cannot co-occur with epistemic modals, which is the prominent reading of the modal in (30B.iii) (due to the present perfect tense), which explains the unacceptability of this sentence. With a deontic reading (aided by present tense) (30B.iii) would receive a narrow scope reading (with ruhig indicating something like 'I don't care, whatever Paul did'), see (31):

(31) Paul kann ruhig NICHT ins Schwimmbad gehen.

'Whatever! Paul can NOT go to the pool: I don't care.'

The wide scope reading would be infelicitous in (31): the reassuring meaning of ruhig is misplaced in a denial.

Amongst the other examples in (30) only (30B.i) with eben allows a wide scope reading, which in this case is a denial reading. Eben has been argued to do different things by different linguists. Most subscribe to the view that it signals immutability of the state-ofaffairs the proposition denotes (e.g. Weydt 1969; Helbig 1988; Autenrieth 2002). Thurmair (1989) argues that eben signals that the proposed state-of-affairs is obvious. Importantly, eben has no retrieval function like doch or $j a$ have. ${ }^{30}$ This suggests that it only contributes to the meaning of the current utterance. Since (30B.i) on a wide scope reading is a denial, I suggest that the speaker uses eben to express the obviousness of his/her rejecting the previous utterance.

Before we turn to the narrow scope reading of the eben-example let us consider why (30B.ii) with einfach ('just', 'simply') does not have a wide scope reading. The particle einfach is described by Thurmair (1989) as signalling obviousness, similarly to eben, with the difference that with einfach this obviousness only holds for the speaker. Now, if the state-of-

\footnotetext{
${ }^{29}$ For some exceptions and discussion, see Schwager (2010).

${ }^{30}$ According to Karagjosova (2004), eben like doch and ja signals familiarity and indicates that the inferential relation between the preceding and the current utterance is common knowledge. Yet, she takes eben to be indifferent with respect to the question whether these pieces of common knowledge are active beliefs or not. So I conclude that there is not actually a retrieval function associated with eben.
} 
affairs denoted by the proposition is only obvious for the speaker it is not well-suited as a denial because it cannot be convincing for the addressee. This is why (30B.ii) is infelicitous with a wide scope reading.

Turning to the narrow scope readings of the sentences with eben and einfach we find that they are incoherent in the given context. I suggest that the reason for this is the implicature conveyed by the contextual sentence (30A), viz. $\neg \square \mathrm{q} \Leftrightarrow \diamond \neg q$, which is the proposition expressed by the B-sentences. Expressly marking that proposition as obvious is redundant: the addressee is already aware of the implicature - otherwise s/he would not have chosen the possibility modal (by the Gricean maxims of quantity and quality). So pointing out the obviousness of this meaning component is inadequate. We observe that CG-managing operators in general seem to be sensitive to implicatures of the previous utterance, although the details differ. Recall that with doch and $j a$ the retrieval of an implicature was not possible if the implicature was a component of the directly preceding utterance.

The particle schon has often been described as partly accepting and partly rejecting the previous utterance (e.g. Thurmair 1991: 148). For instance, schon may signal that the speaker confirms the previous utterance but wishes to rule out a (defeasible) entailment of it. Egg, (this volume) offers the following definition: ${ }^{31}$

$$
\llbracket \text { schon } \rrbracket=\lambda p_{0} \lambda p_{-1}\left[p_{0} \wedge p_{-1} \wedge \text { according to CG } p_{-1} \text { defeasibly entails: } \neg p_{0}\right]
$$

Since accepting (parts of) a previous utterance is incompatible with the meaning contribution of FALSUM, the modal particle schon is impossible in a denial, and therefore the wide scope reading in (30B.iv) is unavailable:

$$
\begin{aligned}
& * \llbracket \operatorname{schon} \rrbracket(30 \mathrm{~A})(30 \mathrm{~B} . i v)=\text { FALSUM }(\mathrm{p}) \wedge \mathrm{p} \wedge \mathrm{p} \text { defeasibly entails FALSUM }(\mathrm{p}) \\
& \text { denial reading intended }
\end{aligned}
$$

The meaning of (30B.iv) with narrow scope of the negation in the context of (30A) is given in (34), where $p_{0}=\diamond \rightarrow q$, and $p_{-1}=\diamond q$. What we find is that the defeasible entailment is a contradiction for all contingent propositions.

$$
\begin{aligned}
& * \llbracket \text { schon } \rrbracket(30 \mathrm{~A})(30 \mathrm{~B} . \mathrm{iv})=\diamond \neg \mathrm{q} \wedge \diamond \mathrm{q} \wedge \diamond \mathrm{q} \text { defeasibly entails } \mathrm{s}_{\mathrm{CG}} \neg \diamond \neg \mathrm{q} \\
& =\diamond \neg \mathrm{q} \wedge \diamond \mathrm{q} \wedge \diamond \mathrm{q} \text { defeasibly entails } \mathrm{CG} \square \mathrm{q}
\end{aligned}
$$

This seems to be a good reason for the unacceptability of (30B.iv). Unfortunately, the picture is a bit more complicated. Consider the discourse in (35). ${ }^{32}$ The meaning of the schonutterance is given in (36). Again, the defeasible entailment is a contradiction for all contingent propositions $p$. Yet the discourse is perfectly acceptable.

\footnotetext{
${ }^{31}$ Note again (cf. fn. 17) that the restriction to previous and current utterance is a gross simplification. Egg (this volume) points out that the propositions which are the arguments of schon often do not correspond to the propositions expressed by these utterances. Importantly, though, deviations from this simple correspondence are reserved for discourse-initial occurrences of utterances with modal particles, and for cases where the 'previous utterance' does not provide a singular proposition (again non-declarative sentences). As I am only concerned with discourses consisting of two adjacent declaratives this simplification is harmless. The conclusion reached below - that the semantics in (32) is too restrictive - is independent of this simplification.

32 Thanks to an anonymous reviewer for a similar example.
} 
(35) A: Peter ist klug. Peter is clever
B: Ja, Peter ist schon klug. yes Peter is PART clever

$* \llbracket \operatorname{schon\rrbracket }(35 \mathrm{~A})(35 \mathrm{~B})=\mathrm{p} \wedge \mathrm{p} \wedge \mathrm{p}$ defeasibly entails $\mathrm{sG}_{\mathrm{CG}} \neg \mathrm{p}$

It is important to note that the way B's utterance is to be understood in (35) is not just a repetition of (the meaning of) A's utterance: a plausible reading of B's utterance is that B is considering some characteristics of Peter that are not as positive as his cleverness but $\mathrm{s} / \mathrm{he}$ concedes that Peter indeed is clever. So it seems that a proposition that is defeasibly entailed by the first speaker's utterance - say that being clever defeasibly entails being friendly, competent, not lazy etc. - and that is picked up by schon in the second speaker's utterance does not actually have to be made explicit in that utterance. It is possible for B to continue with a remark such as that Peter is lazy and therefore not suitable for a particular job. The semantics of schon in (32) is too restrictive in this respect. Since the aim of this paper is not to investigate the specific semantics of schon I leave the question of how exactly it should be spelled out open for further research. Let us nevertheless assume for the present purposes that the basic intuition behind (32) and earlier proposals along these lines is on the right track. If we assume that much, why is it that (35A-B) is felicitous whereas (30A-B.iv) is not?

We observed that in the discourse (35A-B) speaker B confirmed A's utterance and (silently) considered some propositions that did not follow from the proposition expressed by A. In (30A-B.iv) speaker B makes explicit an implicature that speaker A's utterance $(\diamond p)$ has: viz. $\neg \square \mathrm{q} \Leftrightarrow \diamond \neg q$. I suggest that for the purpose of a conversation this is not a confirmation (as would be required by schon) because subscribing to the $\diamond \neg q$ would have quite different consequences for future actions of the interlocutors. Recall our purpose-guided hypothetical reasoning example in section 1.2.1: if the purpose of the conversation is to find Peter, uttering $\diamond q$ rather than $\diamond \neg q$ might be taken to be a suggestion to go to the pool and look for Peter there. So what we find is that the confirmation component of schon is not present in this context, which is why this discourse is incoherent.

Let us finally consider (30B.v) with wohl. According to Zimmermann (2004) the particle wohl signals a weak commitment to the proposition whose illocutionary type it modifies. Repp $(2006,2009)$ argues that wohl just like FALSUM is an epistemic illocutionary operator that signals the degrees of strength of the sincerity conditions of a speech act. In the case of wohl the degrees of strength are fairly high. Therefore a combination with FALSUM, which signals that the degrees of strength are zero is impossible. There is no denial reading available. The reasons for the absence of the narrow scope reading of (30B.v) are somewhat unclear to me and need further scrutiny. Thurmair (1989) suggests that wohl explicitly signals to the addressee that $\mathrm{s} / \mathrm{he}$ might object to the current utterance, which in the context of $(30 \mathrm{~A})$ would be incoherent. On the other hand, a combination of wohl with the epistemic possibility modal seems a bit odd even in the absence of negation:

(37) ?Paul kann wohl ins Schwimmbad gegangen sein.

'Paul, I assume, can have gone to the pool.'

I leave these questions for future research.

Let me summarize the findings of this section. We found that modal particles influence the scopal interaction of a modal verb and an accented negative marker. I suggested that this just like in the case of doch and ja - is due to the modal particles being CG-managing operators. The modal particles of this section do not have retrieval functions like doch or $j a$ but they express the speaker's stance towards the current utterance and its role in the 
discourse. This influences the discourse appropriateness of the proposition the particle scopes over. For instance, explicitly pointing out the obviousness of the truth of a proposition in a context where it is clear that the addressee subscribes to the truth of that proposition anyway, is not a cooperative move. We also saw that the modal particles that I investigated in this section interact with FALSUM in a way that is predicted by the analysis of FALSUM which I suggested in section 1.1.2.2.

\subsection{VERUM}

So far I have concentrated on the discourse effects that an accent on the negative marker may have. I assumed that such an accent may indicate a denial reading, which I analyzed as an assertion with the operator FALSUM. In section 1.1.2 I mentioned that it has been suggested (van der Sandt 1991) that denials need not involve a negation at all, i.e. a positive sentence might be viewed as a denial of a negative sentence. One way of signalling such a positive denial seems to be to place an accent on the finite verb:

(38) A: Paul hasn't gone to the pool.

B: Paul HAS gone to the pool.

In this section I will show that matters are not quite so straightforward and that the discourse conditions for an accent on the finite verb are a little surprising from the point of view of positive denials. We shall see that this accent can be used both to express a denial and an affirmation of a previous utterance.

To begin, consider (39), which is another intonational variant of our standard discourse example. In (39), the finite verb carries the main stress. This example seems to be interchangeable with the version where the negation is stressed, i.e. the denial version (ex. (6)). The translation suggests that the effect is similar in English. Note that (39B) can only have a wide scope reading of the negation, no matter what the context is.

(39) A: Paul kann ins Schwimmbad gegangen sein.

B: Paul KANN nicht ins Schwimmbad gegangen sein.

B': Paul kann NICHT ins Schwimmbad gegangen sein. (= (6B))

A: 'Paul can have gone to the pool.'

$B \& B^{\prime}$ : 'Paul CAN'T have gone to the pool.'

Further note that the apparent interchangeability of the accent on the finite verb vs. the negative marker is not dependent on the finite verb being a modal verb:

(40) A: Paul ist ins Schwimmbad gegangen.

Paul is to.the pool gone

B. Paul IST nicht ins Schwimmbad gegangen.

B'. Paul ist NICHT ins Schwimmbad gegangen.

Paul IS not to.the pool gone

A: 'Paul has gone to the pool.'

$B \& B^{\prime}$ : 'Paul HASN'T gone to the pool.'

An accent on the auxiliary or on the finite verb has been argued to be able to signal different kinds of focus: focus on tense, mood, aspect, the lexical contents, or so-called VERUM focus, which originally has been taken as focus on the truth of the proposition (Höhle 
1988, 1992). Often VERUM focus is assumed to be the same as polarity focus. In some recent literature, however, VERUM is not thought to indicate focus, but to be an illocutionary or conversational operator (Romero \& Han 2004; Repp 2009; Gutzmann \& Castroviejo Miró 2011). I already mentioned this above. Romero \& Han (2004) suggest that VERUM expresses that the speaker is certain that the proposition in the scope of VERUM should be in the CG. Repp (2009) links this to the degrees of strength of the sincerity conditions, and assumes that VERUM signals the maximum degree of strength. Let us take this as a working hypothesis for the moment. Note, however, that neither of these proposals formulates conditions on the discourse for the use of VERUM. Gutzmann \& Castroviejo Miró (2011) do take into account some discourse conditions. I will come to this further below.

The above data suggest that VERUM scoping over a negative proposition has the same effects as FALSUM in positive sentences, in other words VERUM $(\neg p)$ seems to be the same as FALSUM $(p)$, and it is tempting to hypothesize that VERUM has the same discourse conditions as FALSUM. However, we shall see that this is not the case. As already mentioned above, VERUM cannot only be used to express a denial but it can also do the 'opposite': it can signal affirmation. This can be seen in examples like (41) where a speaker uses VERUM to confirm something that the interlocutor assumes as well. (41) is from a TV talk show that has been recorded and transcribed in the Fokusdatenbank ('focus data base'), a spoken-language data base developed by Lohnstein \& Stommel (2007-2010).

(41) /DAS sollte /AUCH erwähnt werden wenn wir sagen wir ham die falsche /ZUwanderungspolitik ich stimme ihnen /ZU die /IST falsch a aber wir ham sehr /VIEle zuwanderer nur keine zuwanderungspoli/TIK S21: Phoenix DW9 [78]

'THAT should mentioned as WELL if we say that we have the wrong immiGRAtion politics, I aGREE with you, it $\underline{\boldsymbol{I}}$ wrong, but we have very MANY immigrants but no immigration POlitics.'

Example (42) below is a constructed minimal variant where the accent is placed on the negation instead of on the finite verb, and the context is altered slightly to make the discourse plausible: the relevant discourse portion here contains negative polarity (we do not have the right immigration politics) instead of positive polarity as in the above example. The result is incoherent. This is expected under the analysis of FALSUM given in section 1.1.2.2, according to which $\operatorname{FALSUM}(p)$ can only apply if the preceding utterance entails (strengthened) $p$. This is not given in (42). The preceding utterance entails $\neg p$ in this case.

(42) \#/DAS sollte /AUCH erwähnt werden wenn wir sagen wir ham nicht die richtige /ZUwanderungspolitik ich stimme ihnen /ZU die ist /NICHT richtig a aber wir ham sehr /VIEle zuwanderer nur keine zuwanderungspoli/TIK 'THAT should mentioned as WELL if we say that we do not have the right immiGRAtion politics, I aGREE with you, it is NoT right, but we have very MANY immigrants but no immigration Politics.'

These data suggest that VERUM imposes different conditions on the CG and the immediately preceding utterance than does FALSUM. Further evidence for this conclusion comes from examples like (43) below, where our standard example occurs in the context of an utterance that contains a necessity modal. In this discourse the two accentual patterns are not 
interchangeable: only the pattern with an accent on the finite verb, i.e. (43A-B'), is admissible (I am only interested in the wide scope reading here). ${ }^{33}$

(43) A: Paul muss ins Schwimmbad gegangen sein.

B: Paul KANN nicht ins Schwimmbad gegangen sein.

B': \#Paul kann NICHT ins Schwimmbad gegangen sein. Paul can not to.the pool gone been

'A: Paul must have gone to the pool.'

'B\&B': Paul CAN'T have gone to the pool.'

The fact that (43A-B') is incoherent follows from the definition of FALSUM: (43A) does not entail the strengthened proposition in the scope of FALSUM in (43B'), i.e. (43A) does not entail Paul can have gone to the pool but it is not the case that he must have gone to the pool. Therefore FALSUM cannot occur in this context. VERUM in (43B), in contrast, scopes over the proposition it is not the case that Paul can have gone to the pool. This proposition is incompatible with the proposition expressed in (43A). We have a - felicitous - denial reading.

Although VERUM and FALSUM behave differently in the above discourses they are alike in the restriction that they cannot occur in discourse-initial utterances. The fact that FALSUM is restricted in this way follows from our analysis since the discourse condition for the use of FALSUM in denials is that the previous utterance entails strengthened $p$. If there is no previous utterance that condition is violated. For VERUM, Gutzmann \& Castroviejo Miró (2011) suggest that the operator removes all questions resolved by the utterance it is part of from the partially ordered set that specifies the currently discussable issues, i.e. the question(s) under discussion. This presupposes that there is such a current question under discussion. For our standard discourse, exemplified e.g. in (43A-B), we would have to assume that whether it is possible that Paul went to the pool should have been the current question under discussion. The context, however, was about the necessity of Paul having gone to the pool. This suggests that (43A) and (43B) do not answer the same question-under-discussion. It seems then that the felicity of VERUM in this discourse remains unaccounted for. Nevertheless, we shall see that the notion of question under discussion is necessary to understand the discourse restrictions of VERUM.

In the following I will demonstrate that both expressing affirmation and expressing a denial in an utterance with VERUM are only possible in specific discourse circumstances, which differ for the two types of replies. To appreciate the (un)acceptability of the discourses to be discussed note that I give the judgements for an intonation pattern where in the sentence with VERUM only the finite verb is marked with a falling accent and the remainder of the sentence is deaccented. Some of the judgements will change if there is another accent for instance on an object DP (e.g. in (49) further below). I will come back to that. As before, I restrict my discussion to declaratives - both as context and as target utterance. ${ }^{34}$

(44) below is the 'mirror image' of (43): in (44) utterance A contains the possibility modal and utterance B contains the necessity modal. Neither an accent on the finite verb nor

\footnotetext{
${ }^{33}$ One might wonder if we are still dealing with VERUM - after all, the lexical contents of the two modal verbs is different, so we might be dealing with focus on the lexical contents. However, this leaves the negation in (43B) unaccounted for: it is not the case that the two utterances only differ in the modal verb that is used. So I assume that we are not dealing with lexical focus.

${ }^{34}$ See e.g. Gutzmann \& Castroviejo (2011) for questions and imperatives.
} 
an accent on the negative marker seems to produce a coherent discourse (again, I am only interested in the wide scope reading). For FALSUM this result is expected. For VERUM we observe that utterance B is not a denial of the previous utterance: the proposition expressed by $\mathrm{A}(\diamond q)$ is compatible with the proposition VERUM scopes over in B $(\neg \square q)$. So B cannot be used as a rejection. Yet, neither does B seem to work as an affirmation.

(44) A: Paul kann ins Schwimmbad gegangen sein.

B: \#Paul MUSS nicht ins Schwimmbad gegangen sein.

B': \#Paul muss NICHT ins Schwimmbad gegangen sein.

Paul can not to.the pool gone been

wide scope

'A: Paul can have gone to the pool.'

'B\&B': It is not the case that Paul must have gone to the pool.'

Let us look at this in greater detail and start with the conditions for expressing an affirmation by using VERUM. We shall see that utterance A must (defeasibly) entail B but that there are further discourse conditions to license the use of VERUM. Consider (45), where A entails the proposition under the scope of VERUM in B, but not vice versa. This discourse is only felicitous if the question whether Paul had fruit yesterday (i.e. the weaker proposition) was the question under discussion already before the utterance of $\mathrm{A}$. B can be uttered to express that in view of the fact presented in A, that Paul had a banana yesterday, the proposition that Paul had fruit yesterday - which had been at issue earlier on - according to speaker B should be added to the CG because the sincerity conditions come with a maximal degree of strength. Without this kind of context (45) is incoherent.

(45) A: Paul hat gestern eine Banane gegessen.

Paul has yesterday a banana eaten

B: \#Genau. Paul HAT gestern Obst gegessen. precisely Paul has yesterday fruit eaten

'A: Paul had a banana yesterday.'

'B: Precisely. Paul did have fruit yesterday.'

Only felicitous if [Q (Paul had fruit yesterday)] is at issue before A's utterance.

If A's utterance does not (defeasibly) entail the proposition expressed by B, e.g. if B's utterance expresses a stronger proposition than A as in (46) the discourse is incoherent in any context, i.e. even if Paul having had a banana yesterday was at issue before.

(46) A: Paul had fruit yesterday.

B: \#Precisely. Paul DID have a banana yesterday.

This is expected if we take into account overall discourse coherence: A's utterance cannot be taken as an argument to support B's intention (fed by a maximal degree of strength of sincerity) to add to the CG the proposition that Paul had a banana yesterday, which was at issue before: eating fruit does not (defeasibly) entail eating a banana.

More generally, we can make sense of the discourse requirement on the use of VERUM, viz. that the proposition in the scope of VERUM should have been at issue even before the preceding utterance if we consider that a simple agreement with the interlocutor's proposal to add a proposition to the CG could be signaled by silence or a simple yes (see section 1.1.1). Pointing out that there is a particularly high degree of strength for adding a proposition to the CG must be motivated - the proposition must have been up for negotiation before, or for a longer stretch of discourse. This is further supported by the fact that VERUM cannot be used to 
affirm the proposition that was uttered by the previous speaker if not uttered in a such more complex discourse (the 'well' in (47) indicates that it is not enough that the question whether Paul had a banana is answered by A).

(47) A: Paul had a banana.

B: \#(Yes.) Paul DID have a banana.

Only felicitous if [Q (Paul had a banana)] is at issue 'well' before A's utterance.

Let us turn to VERUM in denials. In (48) VERUM scopes over the negation of an entailment of A's utterance. This is a stronger proposition than the negation of the proposition expressed by A would be, i.e. the proposition expressed by B entails the negation of $\mathrm{A}$. The result is a denial of A by $B$.

(48) A: Paul hat gestern eine Banane gegessen.

Paul has yesterday a banana eaten

B: Paul HAT gestern kein Obst gegessen.

Paul has yesterday no fruit eaten

'A: Paul had a banana yesterday.'

'B: Paul DIDn't have any fruit yesterday.'

In (49) the scenario is exactly the same: VERUM scopes over the negation of an entailment of A. This time the proposition VERUM scopes over is positive. Curiously, the result is incoherent unless the question whether Paul had a banana yesterday was at issue before A's utterance. ${ }^{35}$

(49) A: Paul hat gestern kein Obst gegessen.

Paul has yesterday no fruit eaten

B: \#Paul HAT gestern eine Banane gegessen.

Paul has yesterday a banana eaten

'A: Paul did not have any fruit yesterday.'

'B: Paul DID have a banana yesterday.'

Only felicitous if [Q (Paul had a banana yesterday)] is at issue before A's utterance.

The difference in acceptability between (48) and (49) at first sight is quite mysterious ${ }^{36}$ and I do not have the space to explore it in sufficient depth here. However, I would like to point out

\footnotetext{
${ }^{35}$ Note that the fact that fruit appears in utterance A and banana in utterance B in (49) follows from the intention to produce a denial reading here. If the two elements swapped places the discourse would be incoherent. Recall the related discussion in the context of affirmation (example (46) above).

${ }^{36}$ For the affirmation context it does not make a difference whether VERUM scopes over a positive or a negative proposition:

(i) A: Paul hat gestern kein Obst gegessen.

Paul has yesterday no fruit eaten

B: \#Genau. Paul HAT gestern keine Banane gegessen.

precisely Paul has yesterday no banana eaten

'A: Paul didn't have any fruit yesterday.'

'B: Precisely. Paul DIDn't have a banana yesterday.'

Only felicitous if [Q (Paul didn't have a banana yesterday)] is at issue before A's utterance.
} 
that this difference finds an echo in deaccentuation patterns we observe in other contexts. Consider (50) and (51) below. Deaccentuation of everything apart from the elements in small capitals (which come with a rising or falling accent) in these examples is only possible if the more specific term in the object position (banana) occurs in a sentence preceding another sentence with a more general term in the object position (fruit).

(50) a. Erst hat /PAUL eine Banane gegessen ...

first has Paul a banana eaten

... und dann hat MMARIA Obst gegessen. and then has Maria fruit eaten.

'First Paul ate a banana and then Maria ate fruit.'

b. *Erst hat /PAUL Obst gegessen und dann hat IMARIA eine Banane gegessen. 'First Paul ate fruit and then Maria ate a banana.'

(51) a. Erst wollte /PAUL keine Banane essen ...

first wanted Paul no banana eat

... und dann wollte IMARIA kein Obst essen.

and then wanted Maria no fruit eat.

'First Paul didn't want to eat a banana, and then Maria didn't want to eat fruit.'

b. *Erst wollte /PAUL kein Obst essen

... und dann wollte $\backslash$ MARIA keine Banane essen.

'First Paul didn't want to eat fruit, and then Maria didn't want to eat a banana.'

These patterns follow from theories of Givenness ${ }^{37}$ like Schwarzschild (1999), where (very roughly) a referent is given and can be deaccented if the utterance $u$ it occurs in is entailed by a salient previous utterance (provided focus-marked phrases in $u$ are replaced with existentially bound variables). For instance, in (50) [Mary] ${ }_{F O C}$ ate fruit is given in the context of Paul ate a banana $(=(50 \mathrm{~A}))$, because the focus-marked Mary is replaced by the existentially closed variable $x$ and $\exists x . x$ ate fruit is entailed by (50A). (51) indicates that the same holds for negative sentences.

With respect to our data in (48) and (49) we observe that (48) 'follows' the licensing pattern as far as the VPs are concerned: eating a banana entails eating fruit. This does not hold for (49). This suggests that we might have a prosodic reason for why (48) is acceptable but (49) is not. This is further corroborated by the observation that the discourse in (49) can be rendered felicitous without a wider context, i.e. behaves like (48), if there is a (strong accent) on banana, so banana would be replaced by a variable that would get existentially bound. This then would be fine with the entailment on the VP level.

On the sentence, or utterance, level things are a bit more complicated. Utterance $\mathrm{A}$ in (48) does not entail utterance B. The two have opposing polarities. Furthermore, the negative marker in (48B) is not accented. Hence we might assume that the negation is not F-marked and cannot be replaced by a variable. Now, the negative marker in this example can be accented - if the finite verb is unaccented. Yet, this still does not mean that we necessarily deal with polarity focus here. I suggest that the result would actually be the FALSUM reading, which arises if there is an accented negative marker in an utterance that is incompatible with the previous utterance. The difference between FALSUM and polarity focus is that the former is

\footnotetext{
${ }^{37}$ The general role of givenness for the use of VERUM has been noted before, e.g. Gutzmann \& Castroviejo Miró (2011). However, the details as specified in the main text have not been explored before.
} 
a CG-managing operator whereas the latter 'only' indicates semantic alternatives. I assume that polarity focus occurs in answers to (positive) yes-no questions, and that in denial contexts we find FALSUM. With respect to (48) I propose that the fact that not both the negative marker and the finite verb can be accented in one utterance can easily be explained if we assume that FALSUM and VERUM indicate different, incompatible degrees of strength (zero vs. maximal).

The givenness-related accentual patterns of discourses involving negation require more detailed investigation, which I cannot provide here. For the present purposes I assume that the reason for the difference between (48) and (49) is a prosodic one. In the former the VP in A entails the VP in B, which is why we can have deaccentuation. In the latter the VP in A does not entail the VP in B, which is why we cannot have deaccentuation.

Summarizing the discussion of the discourse conditions of VERUM I propose the following (tentative) analysis of the discourse conditions of VERUM. I propose that VERUM signals the maximum degree of strength of the sincerity conditions and thereby expresses that the speaker is certain that the proposition in the scope of VERUM should be in the CG (i.e. basically following Romero \& Han 2004; Repp 2006, 2009). In addition, the utterance containing VERUM is subject to a number of discourse conditions. Below I give the meaning of VERUM and a non-exhaustive list of discourse contexts where VERUM can occur, which is based on the observations that I made in the course of the discussion (recall that CG does not include $u_{n-1}$ ). A precise analysis of VERUM must await further research.

$$
\text { [VERUM } \rrbracket^{x}=\lambda p_{<\mathrm{s}, \mathrm{t}} \lambda \boldsymbol{w} . \forall w^{\prime} \in \operatorname{Epi}_{x}(w)\left[\forall w^{\prime \prime} \in \operatorname{Conv}_{x}\left(w^{\prime}\right)\left[p \in \mathrm{CG}_{w^{\prime \prime}}\right]\right]
$$

(cf. Romero \& Han 2004)

Some admissible discourse contexts for utterance $u_{n}$ with $\llbracket \operatorname{VERUM} \rrbracket^{x}(p)$ :
(i) affirmation
a. $\mathrm{Q}(\mathrm{p}) \in \mathrm{CG}$
b. $\mathrm{u}_{n-1}$ entails $p$
(ii) denial of the form VERUM [p]
a. $\mathrm{Q}(\mathrm{p}) \in \mathrm{CG}$
b. $\mathrm{u}_{n-1}$ entails $\neg p$
(iii) denial of the form VERUM $[\neg \mathrm{p}]$
a. $\mathrm{Q}(\mathrm{p}) \notin \mathrm{CG}$
b. $u_{n-1}$ entails $\neg p$
c. the accentual pattern of $u_{n}$ is licensed by considerations of givenness

\subsection{Summary}

I have argued in this paper that modal particles, FALSUM and VERUM are CG-managing operators. They indicate the CG status of a proposition by indicating whether or not the proposition is part of the CG, by indicating the interlocutors' current stance towards the proposition, and by indicating how the CG should develop. The CG status of a proposition has consequences for its discourse appropriateness, i.e. CG-managing operators place conditions on the discourse context. This may influence the availability of certain truthconditional readings of a proposition, which I illustrated in detail for the interaction of the negation with epistemic modal verbs in German. Furthermore, I demonstrated in what way the combination of CG-managing operators in an utterance depends on their specific meaning contribution. For instance, we saw that rejecting and retrieving a proposition at the same time is impossible (e.g. when combining FALSUM and doch), or that partly agreeing to the truth of a proposition and rejecting it at the same time is impossible (e.g. when combining FALSUM and schon).

The discussion has shown that the assumption that there is a negative operator that does not operate on the level of the proposition but is a CG-managing operator (FALSUM) can explain a wide range of data and makes possible a unified analysis for certain parallel effects 
in declaratives and in questions, essentially corroborating earlier suggestions in Repp (2006, 2009). Furthermore, the discussion of VERUM has revealed that this operator is subject to discourse conditions that had been unknown so far and that deserve much closer scrutiny in future research. We also saw that FALSUM and VERUM empirically sometimes overlap in interesting ways, i.e. seemingly express more or less the same (e.g. a denial), and still we observed that the two operators impose quite different conditions on their occurrence in discourse.

I have taken up, and developed further, threads in the current discussion on the nature of the $\mathrm{CG}$, which emphasizes the need for a wider notion of CG than the set of propositions that the interlocutors hold to be true. I have suggested that the CG status of a proposition should also be part of the CG, which opens up an interesting perspective on the interplay of truthconditional and non-truth-conditional meaning.

\subsection{References}

Alston,W.P. (2000) Illocutionary acts and sentence meanings. Cornell University Press.

Anscombre, J.C. \& O. Ducrot (1983). L'Argumentation dans la langue. Brussels: Pierre Mardaga.

Autenrieth, T. (2002). Heterosemie und Grammatikalisierung bei Modalpartikeln. Tübingen: Niemeyer.

Büring, D. \& C. Gunlogson (2000). 'Aren't positive and negative polar questions the same?' Ms. available at semanticsarchive.net

Carston, R. (1996). 'Metalinguistic negation and echoic use'. Journal of Pragmatics 25, 309-330.

Castroviejo Miró, E. (2006). Wh-Exclamatives in Catalan. PhD thesis. Barcelona: University of Barcelona.

Chierchia, G. (2004). 'Scalar implicatures, polarity phenomena and the syntax/pragmatics interface.' In A. Belletti (ed.), Structures and Beyond. Oxford: Oxford University Press, 39-103 .

Cornides, T. (1969). 'Der Widerruf von Befehlen'. Studium Generale 22, 1215-1263.

Dummet, M. (1973). Frege. Philosophy of Language. London: Duckworth.

Ehrich, V. (2001). 'Was nicht müssen und nicht können (nicht) bedeuten können: Zum Skopus der Negation bei den Modalverben des Deutschen'. In: R. Müller \& M. Reis (eds.), Modalität und Modalverben im Deutschen. Linguistische Berichte, Sonderheft 9. Hamburg: Helmut Buske Verlag, 149-176.

Egg, M. (this volume). 'Discourse particles, CG, and felicity conditions'. In: D., Gutzmann \& H.-M. Gärtner (eds.), Expressives and beyond. Explorations of conventional non-truth-conditional meaning. Oxford: Oxford University Press.

Espinal, M. T. (2000). 'Expletive negation, negative concord and feature checking'. Catalan Working Papers in Linguistics 8, 47-69.

von Fintel, K. \& A. Gillies (to appear). 'Might made right'. In: A. Egan \& B. Weatherson (ed.), Epistemic Modality. Oxford: OUP.

Geurts, B. (1998). 'The mechanisms of denial'. Language 74, 274-307.

Geurts, B. (2009). 'Scalar implicature and local pragmatics. Mind and Language 24, 51-79.

Groenendijk, J. \& M. Stokhof (1984). Studies on the Semantics of Questions and the Pragmatics of Answers. PhD book. University of Amsterdam.

Grosz, P. (2009). 'German particles, modality, and the semantics of imperatives'. In: S. Lima, K. Mullin \& B. Smith (ed.), Proceedings of NELS 39. Amherst, MA: GLSA.

Gutzmann, D. \& Castroviejo Miró, E. (2011). 'The dimensions of VERUM'. In: O. Bonami \& P. Cabredo Hofherr (eds.): Empirical Issues in Syntax and Semantics 8. 143-165.

Harnish, R.M. (2005). 'Commitments and speech acts.' Philosophica 75, 11-41.

Helbig, G. (1988). Lexikon deutscher Partikeln. Leipzig: Verlag Enzyklopädie.

Höhle, T. (1988). 'VERUM-Fokus'. Sprache und Pragmatik 5, 2-7.

Höhle, T. (1992). 'Über Verum-Fokus in Deutschen'. In: J. Jacobs (ed.), Informationsstruktur und Grammatik. Linguistische Berichte Sonderheft 4/1991-1992. Opladen: Westdeutscher Verlag, 112-141. 
Horn, L. (1985). 'Metalinguistic negation and pragmatic ambiguity'. Language 61, 121-174.

Horn, L. (1989). A Natural History of Negation. Chicago: The University of Chicago Press.

Ibáñez, Roberto (1972). Negation im Spanischen. München: Fink.

Jacobs, J. (1982). Syntax und Semantik der Negation im Deutschen. München: Fink.

Jacobs, J. (1991). 'On the semantics of modal particles'. In: W. Abraham (ed.), Modal particles: Descriptive and theoretical investigations on the logical, syntactic and pragmatic properties of modal particles in German. Amsterdam: Benjamins, 141-162.

Karagjosova, E. (2004). The meaning and function of German modal particles. $\mathrm{PhD}$ thesis. University of Saarbrücken.

Karttunen, L. (1974). 'Presuppositions and linguistic context'. Theoretical Linguistics 1, 181-194.

Krifka, M. (2001). 'Quantifying into question acts'. Natural Language Semantics 9, 1-40.

Krifka, M. (2008). 'Basic notions of information structure'. Acta Linguistica Hungarica 55, 243-276.

Krifka, M. (2010). 'How to interpret 'expletive' negation under bevor in German'. In: T. Hanneforth \& G. Fanselow (eds.), Language and Logos. Studies in Theoretical and Computational Linguistics. Berlin: Akademie Verlag, 214-236.

Ladd, R. D. (1981). 'A first look at the semantics and pragmatics of negative questions and tag questions'. Papers from the Seventeenth Regional Meeting of the Chicago Linguistic Society, 164171.

Lakoff, R. (1971). 'If's, and's and but's about conjunction.' In: C.J. Fillmore \& D.T. Langendoen (eds.), Studies in Linguistic Semantics. New York: Holt, Rinehart \& Winston. 114-149.

Lang, E. (1991). 'Koordinierende Konjunktionen.' A. von Stechow \& D. Wunderlich (eds.), Semantik. Ein internationales Handbuch zeitgenössischer Forschung. Berlin: de Gruyter. 597-623.

Lascarides, A. \& N. Asher (2009). 'Agreements, disputes and commitments in dialogue'. Journal of Semantics 26(7), 109-158.

van Leusen, N. (2004). 'Incompatibility: A Diagnosis of Correction'. Journal of Semantics 21(4), 415-442.

van Leusen, N. (2007). Description Grammar for Discourse. PhD thesis. University of Nijmegen.

Lewis, D. (1979). 'Scorekeeping in a language game'. Journal of Philosophical Logic 8, 339-359.

Lindner, K. (1991). 'Wir sind ja doch alte Bekannte. The use of German ja and doch as modal particles'. In: W. Abraham, (ed.), Modal particles: Descriptive and theoretical investigations on the logical, syntactic and pragmatic properties of modal particles in German. Amsterdam: Benjamins, 163-201.

Lohnstein, H. \& H. Stommel (2007-2010). 'Fokusdatenbank'. http://www.fokus-db.de/

Meibauer, J. (1990). 'Sentence mood, lexical categorial filling and non-propositional nicht in German'. Linguistische Berichte 130, 441-465.

Meibauer, J. (1994). Modaler Kontrast und konzeptuelle Verschiebung. Studien zur Syntax und Semantik deutscher Modalpartikeln. Tübingen: Niemeyer.

Merin, A. (1996). Die Relevanz der Relevanz. Fallstudie zur formalen Semantik der englischen Konjunktion but. Unpublished Habilitation Thesis. Stuttgart University.

Muller, C., (1991). La négation en français: Syntaxe, sémantique et éléments de comparison avec les autres langues romanes. Librairie Droz: Genève.

Öhlschläger, G. (1989). Zur Syntax und Semantik der Modalverben des Deutschen. Tübingen: Narr.

Penka, D. (2010). Negative Indefinites. Oxford: Oxford University Press.

Penka, D. \& A. von Stechow (2001). 'Negative Indefinita unter Modalverben'. In: R. Müller \& M. Reis (ed.), Modalität und Modalverben im Deutschen. Linguistische Berichte, Sonderheft 9. Helmut Buske Verlag Hamburg, 263-286.

Portner, P. (2007). 'Beyond the CG: The semantics and pragmatics of epistemic modals'. Talk. International Conference on Linguistics in Korea.

Portner, P. \& R. Zanuttini (2000). 'The force of negation in $w h$-exclamatives and interrogatives'. In: L. Horn \& Y. Kato (ed.), Studies in Negation and Polarity, Oxford: Oxford University Press, 193231.

Repp, S. (2006). ' $\neg(A \& B)$. Gapping, negation and speech act operators'. In: J. Spenader \& P. Hendriks (ed.), Research on Language and Computation 4(4). Sonderausgabe zu Ellipsen, 397423.

Repp, S. (2009). Negation in Gapping. Oxford: Oxford University Press. 
Roguska, M. (2008). Exklamation und Negation. Berlin: Logos.

Romero, M. \& C.-h. Han (2004). 'On negative Yes/No Questions'. Linguistics and Philosophy 27, 609-658.

Rosengren, I. (1992). 'Zur Grammatik und Pragmatik der Exklamation'. In: Rosengren, I.(ed.), Satz und Illokution. Bd. I. Tübingen: Niemeyer, 263-306.

Schwager, M. (2010). 'Modality and speech acts: troubled by German 'ruhig'. In: M. Aloni, H. Bastiaanse, T. de Jager \& K. Schulz (ed.), Logic, Language and Meaning. 17th Amsterdam Colloquium. Revised Selected Papers. Lecture Notes in Computer Science, Volume 6042. Springer, 416-425.

Schwarz, B. \& R. Bhatt (2006). 'Light negation and polarity'. In: R. Zanuttini, E. Campos, E. Herburger \& P.H. Portner (ed.), Crosslinguistic research in Syntax and Semantics. Negation, Tense and Clausal Architecture. Georgetown University Press, 199-220.

Schwarzschild, R. (1999). Givenness, AvoidF andother constraints on the placement of accent. Natural Language Semantics 7, 141-177,

Searle, J. (1969). Speech Acts. An Essay in the Philosophy of Language. Cambridge: CUP.

Searle, J. (2001) Rationality in Action. Cambridge, MA: MIT Press

Selkirk, E. (1984). Phonology and Syntax: The Relation between Sound and Structure. Cambridge: MIT Press.

Stalnaker, R. (1978). 'Assertion'. In: P. Cole (ed.), Pragmatics. New York: Academic Press, 215-323. van der Sandt, R. (1991). 'Denial', Papers from CLS, 27(2). The parasession on negation, 331-344.

Stenius, E. (1967). 'Mood and language game.' Synthese 17, 254-274.

Thurmair, M. (1989). Modalpartikeln und ihre Kombinationen. Tübingen: Niemeyer.

Vanderveken, D. (1990). Meaning and Speech Acts. Volume I: Principles of Language Use. Volume II: Formal Semantics of Success and Satisfaction. Cambridge: Cambridge University Press.

Waltereit, R. (2001). 'Modal particles and their functional equivalents: A speech-act-theoretic approach'. Journal of Pragmatics 33, 1391-1417.

Wassermann, R. (2000). Resource-Bounded Belief Revision. PhD thesis. University of Amsterdam.

Weydt, H. (1969). Abtönungspartikel. Die deutschen Modalwörter und ihre französischen Entsprechungen. Bad Homburg: Gehlen.

van der Wouden, T. (1994). 'Polarity and 'illogical negation'. In: M. Kanazawa \& C.J. Piñon (ed.), Dymanics, Polarity, and Quantification. Stanford: CSLI, 17-45.

Yoon, S. (2011). 'Not' in the mood: the syntax, semantics and pragmatics of evaluative negation. PhD thesis. Universiy of Chicago.

Zeijlstra, H.H. (2007). 'On the lexical status of negative indefinites in Dutch and German'. Ms. http://ling.auf.net/lingBuzz/000566.

Zimmermann, M. (2004). 'Zum Wohl': Diskurspartikeln als Satztypmodifikatoren'. Linguistische Berichte 199, 253-286. 